OPEN ACCESS

Edited by:

Xuelei Ma,

Sichuan University, China

Reviewed by:

Stefano Giovagnoli,

University of Perugia, Italy

Shohei Koyama,

Osaka University, Japan

Jinghua Yan,

Chinese Academy of Sciences,

China

Cihui Yan,

Tianjin Medical University Cancer

Institute and Hospital, China

*Correspondence:

Li-WU Fu

fulw@mail.sysu.edu.cn

${ }^{\dagger}$ These authors have contributed equally to this work

Specialty section: This article was submitted to Pharmaceutical Medicine and Outcomes Research,

a section of the journal

Frontiers in Pharmacology

Received: 30 June 2019

Accepted: 30 April 2020

Published: 15 May 2020

Citation:

Zhang J-y, Yan Y-y, Li J-j, Adhikari R and Fu L-W (2020) PD-1/PD-L1 Based Combinational Cancer Therapy: lcing on the Cake.

Front. Pharmacol. 11:722. doi: 10.3389/fphar.2020.00722

\section{PD-1/PD-L1 Based Combinational Cancer Therapy: Icing on the Cake}

\author{
Jian-ye Zhang ${ }^{1,2 \dagger}$, Yan-yan Yan ${ }^{3 \dagger}$, Jia-jun $\mathrm{Li}^{2}$, Rameshwar Adhikari ${ }^{4}$ and $\mathrm{Li}$-wu Fu ${ }^{1 *}$ \\ 1 State Key Laboratory of Oncology in Southern China, Cancer Center, Sun Yat-Sen University, Guangzhou, China, ${ }^{2}$ Key \\ Laboratory of Molecular Target \& Clinical Pharmacology, School of Pharmaceutical Sciences \& the Fifth Affiliated Hospital, \\ Guangzhou Medical University, Guangzhou, China, ${ }^{3}$ Institute of Respiratory and Occupational Diseases, Collaborative \\ Innovation Center for Cancer, Medical College, Shanxi Datong University, Datong, China, ${ }^{4}$ Research Centre for Applied \\ Science and Technology, Tribhuvan University, Kirtipur, Nepal
}

Cancer has been a major global health problem due to its high morbidity and mortality. While many chemotherapy agents have been studied and applied in clinical trials or in clinic, their application is limited due to its toxic side effects and poor tolerability. Monoclonal antibodies specific to the PD-1 and PD-L1 immune checkpoints have been approved for the treatment of various tumors. However, the application of PD-1/PD-L1 inhibitors remains suboptimal and thus another strategy comes in to our sight involving the combination of checkpoint inhibitors with other agents, enhancing the therapeutic efficacy. Various novel promising approaches are now in clinical trials, just as icing on the cake. This review summarizes relevant investigations on combinatorial therapeutics based on PD-1/PD-L1 inhibition.

Keywords: cancer, PD-1, PD-L1, immunotherapy, combinational therapy

\section{INTRODUCTION}

Cancer has become one of the major problems threatening human health based on its high rates of morbidity and mortality (Huang and Fu, 2015; Zhang et al., 2016; Zhang et al., 2017; Huang et al., 2020). Chemotherapeutic drugs play a major role in cancer treatment (Shi et al., 2011; Lin et al., 2017a; Lin et al., 2017b; Jiang et al., 2019). It is undeniable that these treatments are effective at present, but they also destroy the physiological state of normal cells while killing tumor cells, resulting in irreversible damage and therefore poor patient tolerability (Shi et al., 2007; Kathawala et al., 2015; Siegel et al., 2018; Liu et al., 2019). Recently, cancer immunotherapy has been on the rise. It has been shown that immunotherapy has achieved excellent therapeutic efficacy in a variety of tumors, including melanoma, non-small cell lung cancer, renal cell carcinoma, colorectal cancer, as well as breast cancer (Hanahan and Weinberg, 2011; Siegel et al., 2017; Sanmamed and Chen, 2018; Yu et al., 2019). Antibodies specifically against programmed death-1 (PD-1), programmed deathligand 1 (PD-L1), and cytotoxic T lymphocyte antigen 4 (CTLA-4) (e.g., ipilimumab, tremelimumab) are regarded as recent breakthroughs in cancer immunotherapy (Quezada and Peggs, 2013; Herbst et al., 2014; Turajlic et al., 2018; Rahimi Kalateh Shah Mohammad et al., 2020).

\section{PD-1/PD-L1 OVERVIEW}

PD-1 pertains to a suppressive T-cell receptor that is generally expressed by activated $\mathrm{T}$ cells, and antigen-specific T cells, which are chronically exposed to various antigens (Day et al., 2006; 
Tian et al., 2019; Wang and Wei, 2019). PD-1 is highly selective for immune-inhibitory signals that are mediated by programmed death-ligand 1 ( $\mathrm{PD}-\mathrm{L} 1, \mathrm{~B} 7-\mathrm{H} 1$ ), which is generated by malignant cells, myeloid-derived suppressor cells (MDSCs), and leukocytes (Iwai et al., 2002; Blank et al., 2004; Von Knethen and Brüne, 2019). Cancer cells escape immune responses by overexpressing PD-L1 (Figure 1) (Okazaki and Honjo, 2007; Markham, 2016; Cao et al., 2019). The immune system is activated by diseases, whereas PD-L1 inhibits the immune system by preventing foreign antigen-specific $\mathrm{T}$ cells from accumulating and reducing antigen-specific $\mathrm{CD}^{+} \mathrm{T}$ cell proliferation (Trautmann et al., 2006; Sanmamed and Chen, 2018). The inhibitory effect of therapeutic antibodies on PD-1/PD-L1 is expected to be highly specific to tumor antigen-specific $\mathrm{T}$ cells and exhibits lower specificity for auto-reactive $\mathrm{T}$ cells (Sznol and Chen, 2013; Homet Moreno et al., 2015). It has been recently confirmed that $\mathrm{PD}-1 / \mathrm{PD}-\mathrm{L} 1$ treatment can regulate $\mathrm{T}$-cell activation, including the disruption of suppression of $\mathrm{T}$ cell receptor (TCR) activation that is caused by PI3K/Akt/Ras-MEK/ERK, as well as the negative feedback loop involving the cell cycle, thereby leading to apoptosis (Day et al., 2006; Butte et al., 2007; Quigley et al., 2010; Markham, 2016; Kamta et al., 2017; Li X. et al., 2019).

\section{DRUGS TARGETING PD-1/PD-L1}

Until now, six PD-1/PD-L1 targeted drugs have been listed in dozens of countries in Europe and United States, which are made up of three PD-1 antibodies and three PD-L1 antibodies (Sanmamed and Chen, 2018). See Table 1 for details. In addition, four innovative anti-PD-1/PD-L1 mAbs have been on the Chinese market, including toripalimab, sintilimab, camrelizumab, and tislelizumab.

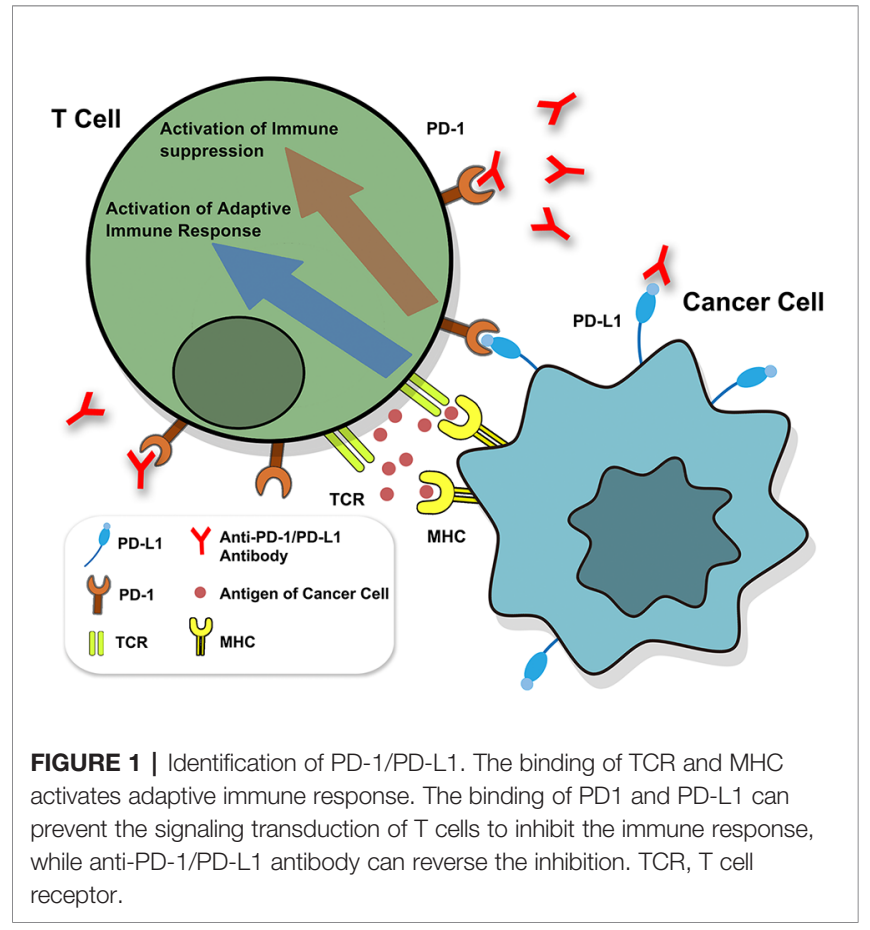

\section{ANTI-PD-1/PD-L1 DRUGS BASED COMBINATIONAL THERAPY}

\section{Nivolumab Based Combinational Therapy Preclinical Study}

Synergistic antitumor activity in mouse MC38 and CT26 colorectal tumor models was observed with concurrent, but not sequential CTLA-4 and PD-1 blockade. Significant antitumor activity was maintained using a fixed dose of antiCTLA-4 antibody with decreasing doses of anti-PD-1 antibody

TABLE 1 | Six PD-1/PD-L1 targeted drugs

\begin{tabular}{|c|c|c|c|c|c|c|}
\hline Abbreviation & O drug & K drug & T drug & I drug & B drug & L drug \\
\hline Trade name & Opdivo & Keytruda & Tecentriq & Imfinzi & Bavencio & Libtayo \\
\hline $\begin{array}{l}\text { Common } \\
\text { name }\end{array}$ & Nivolumab & Pembrolizumab & Atezolizumab & Durvalumab & Avelumab & Cemiplimab \\
\hline Manufacturer & $\begin{array}{l}\text { Bristol-Myers Squibb, } \\
\text { USA }\end{array}$ & Merck, USA & Genentech, USA & AstraZeneca, UK & Merck, USA & $\begin{array}{l}\text { Regeneron } \\
\text { Pharmaceuticals Inc }\end{array}$ \\
\hline Target & PD-1 & PD-1 & PD-L1 & PD-L1 & PD-L1 & PD-1 \\
\hline Indication & $\begin{array}{l}\text { Melanoma, metastatic } \\
\text { squamous NSCLC, etc. }\end{array}$ & $\begin{array}{l}\text { Melanoma, } \\
\text { NSCLC, } \\
\text { renal cell carcinoma, } \\
\text { head and neck } \\
\text { squamous cell carcinoma, } \\
\text { etc. }\end{array}$ & $\begin{array}{l}\text { Urothelial } \\
\text { carcinoma }\end{array}$ & $\begin{array}{l}\text { NSCLC, } \\
\text { urothelial } \\
\text { carcinoma }\end{array}$ & $\begin{array}{l}\text { Merkel cell } \\
\text { carcinoma, } \\
\text { urothelium } \\
\text { carcinoma }\end{array}$ & $\begin{array}{l}\text { metastatic cutaneous } \\
\text { squamous cell carcinoma } \\
\text { (CSCC) or locally } \\
\text { advanced CSCC who are } \\
\text { not candidates for curative } \\
\text { surgery or curative } \\
\text { radiation. }\end{array}$ \\
\hline Approval year & 2014 & 2014 & 2016 & 2017 & 2017 & 2018 \\
\hline Time to & 2018 & 2018 & - & - & - & \\
\hline
\end{tabular}


in the MC38 model. Immunohistochemical and flow cytometric analyses confirmed that $\mathrm{CD}^{+} \mathrm{T}$ cells accumulated at the tumor margin and infiltrated the tumor mass in response to the combination therapy, resulting in favorable effector and regulatory $\mathrm{T}$-cell ratios, increased pro-inflammatory cytokine secretion, and activation of tumor-specific T cells. Similarly, in vitro studies with combined ipilimumab and nivolumab showed enhanced cytokine secretion in superantigen stimulation of human peripheral blood lymphocytes and in mixed lymphocyte response assays. In a cynomolgus macaque toxicology study, dose-dependent immune-related gastrointestinal inflammation was observed with the combination therapy, which had not been observed in previous single agent cynomolgus studies. Together, these in vitro assays and in vivo models comprise a preclinical strategy for the identification and development of highly effective antitumor combination immunotherapies (Selby et al., 2016).

\section{Melanoma}

The first clinical trial of combinational treatment of PD-1 plus CTLA-4 inhibitors was reported in 2013 (Wolchok et al., 2013). Here, 53 melanoma patients were treated with nivolumab + ipilimumab, whereas 33 patients received nivolumab alone. Results showed that the efficacy of the combinatorial treatment was superior to ipilimumab or nivolumab alone as earlier reported. In the combinatorial treatment group, the 2 -year survival was $79 \%$, and the objective response rate (ORR) was $42 \%$. Responding patients showed an $80 \%$ tumor reduction, and $17 \%$ of the patients had a complete response (Pico De Coaña et al., 2015). Nivolumab monotherapy and combination with ipilimumab increase proportions of patients achieving a response and survival, versus ipilimumab in patients with metastatic melanoma. In 2015, the United States Food and Drug Administration (USFDA) approved ipilimumab + nivolumab for the treatment of metastatic or unresectable melanoma (Swart et al., 2016).

In a double-blind study involving 142 patients with metastatic melanoma who had not previously received treatment, the ORR and the progression-free survival (PFS) were significantly greater with nivolumab combined with ipilimumab, than that with ipilimumab monotherapy. Combination therapy had an acceptable safety profile (Postow et al., 2015). In a phase 1 doseescalation study, combined inhibition of T-cell checkpoint pathways by nivolumab and ipilimumab was associated with a high ORR, including complete responses, among patients with advanced melanoma. In the advanced melanoma (CheckMate 067), the phase 2 trial (at 2 years of follow-up) revealed that the combination of first-line nivolumab plus ipilimumab might lead to improved outcomes, compared with first-line ipilimumab alone (Hodi et al., 2016). Nivolumab combined with ipilimumab resulted in longer progression-free survival and a higher ORR than ipilimumab alone in a phase 3 trial involving patients with advanced melanoma. In the advanced melanoma patients, significantly longer overall survival (OS) occurred with combination therapy of nivolumab plus ipilimumab or nivolumab alone, than with ipilimumab alone (Wolchok et al., 2017). The following phase 3 trial (at 4 years of follow-up) showed that a durable, sustained survival benefit can be achieved with firstline nivolumab plus ipilimumab or nivolumab alone in the advanced melanoma patients (Hodi et al., 2018). Among patients with advanced melanoma, sustained long-term OS at 5 years was observed in a greater percentage of patients who received nivolumab plus ipilimumab or nivolumab alone, than monotherapy of ipilimumab. In addition, no patients who received regimens containing nivolumab got apparent loss of quality of life. These results suggest encouraging survival outcomes with immunotherapy in this population of patients (Larkin et al., 2019).

In addition, a multicenter open-label randomized phase 2 trial (NCT02374242) was done and revealed nivolumab combined with ipilimumab and nivolumab monotherapy were active in melanoma brain metastases. A high proportion of patients achieved an intracranial response with the combination. Thus, nivolumab combined with ipilimumab should be considered as a first-line therapy for patients with asymptomatic untreated brain metastases (Long et al., 2018).

The above are some evidence that PD- 1 and CTLA-4 are efficacious via dependent immune pathways. The simultaneous inhibition of both pathways can induce synergistic effects.

\section{NSCLC and SCLC}

A single-center phase Ib study investigated the tolerability, safety, and pharmacokinetics of nivolumab combined with standard chemotherapy in patients with advanced non-smallcell lung cancer (NSCLC). Results indicated that combination of nivolumab $10 \mathrm{mg} / \mathrm{kg}$ and chemotherapy showed an acceptable toxicity profile and encouraging antitumor activity in patients with advanced NSCLC (Kanda et al., 2016). In three academic hospitals in the USA, an open-label, non-randomized, phase Ib clinical trial was conducted with patients with ages $\geq 18$ years. These individuals were previously treated histologically or confirmed cytologically to be at stage IIIB or IV NSCLC. From January 2016 to June 2017, 21 patients received ALT-803 (an IL15 superagonist) plus nivolumab at four dose levels. The results showed that the ALT-803 + nivolumab is safe in the outpatient setting, using a dose of ALT-803 at $20 \mu \mathrm{g} / \mathrm{kg}$ that was administered subcutaneously once per week plus nivolumab administered intravenously at $240 \mathrm{mg}$ every 2 weeks. This is the first report on using IL-15 in the treatment of patients with NSCLC, the potential of ALT-803 + nivolumab (Wrangle et al., 2018). In addition, Oshima $Y$, et al. found a higher proportion of reports about Interstitial Pneumonitis (IP) for nivolumab in combination with EGFR-TKI, than treatment with either drug alone, including concomitant and sequential use, and careful monitoring for IP is recommended (Oshima et al., 2018; Li D. et al., 2019).

Hellmann MD, et al. indicated that in SCLC patients, nivolumab plus ipilimumab appeared to provide a greater clinical benefit than nivolumab monotherapy in the high tumor mutational burden tertile (Hellmann et al., 2018). 


\section{Metastatic Sarcoma}

Patients with metastatic sarcoma have limited treatment options. In the two open-label, non-comparative, randomized, phase 2 trials (NCT02500797), the activity and safety of nivolumab alone or in combination with ipilimumab in patients with locally advanced, unresectable, or metastatic sarcoma were investigated. The results indicated nivolumab combined with ipilimumab demonstrated promising efficacy in certain sarcoma subtypes, with a manageable safety profile comparable to current available treatment options. The combination therapy met its predefined primary study endpoint; further evaluation of nivolumab plus ipilimumab in a randomized study is warranted (D'angelo et al., 2018).

\section{Renal-Cell Carcinoma}

Purpose combination treatment with immune checkpoint inhibitors has shown enhanced antitumor activity. The openlabel, parallel-cohort, dose-escalation, phase I CheckMate 016 study evaluated the efficacy and safety of nivolumab plus ipilimumab, and nivolumab plus a tyrosine kinase inhibitor in metastatic renal cell carcinoma (mRCC). This investigation showed that nivolumab plus ipilimumab therapy demonstrated manageable safety, notable antitumor activity, and durable responses with promising OS in patients with mRCC (Hammers et al., 2017).

OS and ORR were significantly higher with nivolumab plus ipilimumab than with sunitinib among intermediate- and poorrisk patients with previously untreated advanced renal-cell carcinoma. Further study showed that treatment-related adverse events, grade 3 or 4 events, and treatment-related adverse events leading to discontinuation were lower in the nivolumab-plus-ipilimumab group than in the sunitinib group (Motzer et al., 2018).

\section{Lymphoma}

In the phase $1 / 2$ study, brentuximab vedotin (BV) and nivolumab administered in combination was an active and well-tolerated first salvage regimen, potentially providing patients with $\mathrm{R} / \mathrm{R} \mathrm{HL}$ an alternative to traditional chemotherapy (Clinical Trials: NCT02572167) (Herrera et al., 2018).

Combining local irradiation with anti-PD-1 checkpoint blockade treatment is feasible and synergistic in refractory Hodgkin's lymphoma. Correlative studies also suggest that the expression of PD-L1, DNA damage response, and mutational tumor burden can be used as potential biomarkers for treatment response (Qin et al., 2018).

The combination of ibrutinib and nivolumab had an acceptable safety profile and preliminary activity was similar to that reported with single-agent ibrutinib in chronic lymphocytic leukemia or small lymphocytic lymphoma, follicular lymphoma, and diffuse large B-cell lymphoma (Clinical Trials: NCT02329847) (Younes et al., 2019).

\section{Colorectal Cancer}

The clinical trial CheckMate-142 evaluated the efficacy and safety of nivolumab + ipilimumab in 119 patients with microsatellite instability-high (MSI-H)/DNA mismatch repair-deficient (dMMR) metastatic colorectal cancer (mCRC). The patients received a combination of $3 \mathrm{mg} / \mathrm{kg}$ nivolumab and $1 \mathrm{mg} / \mathrm{kg}$ ipilimumab at 3-week intervals (for a total of four doses), followed by nivolumab $3 \mathrm{mg} / \mathrm{kg}$ at 2-week intervals (Gourd, 2018; Overman et al., 2018). Approximately 76\% of patients earlier received two or more systemic treatments. The nivolumab + ipilimumab regimen showed acceptable tolerability, high response rate, and significantly higher PFS and OS at 12-month follow-up. Nivolumab + ipilimumab was thus considered as a potential novel treatment option for patients with dMMR/MSI-H mCRC (Sznol, 2014; Gourd, 2018).

The details for clinical trials of nivolumab based combinational therapy were summarized in Table 2 .

\section{Pembrolizumab Based Combinational Therapy \\ Melanoma}

Standard-dose pembrolizumab given in combination with four doses of reduced-dose ipilimumab followed by standard-dose pembrolizumab has a manageable toxicity profile and provides robust anti-tumor activity in patients with advanced melanoma. These data suggest that standarddose pembrolizumab plus reduced-dose ipilimumab might be a tolerable, efficacious treatment option for patients with advanced melanoma (Clinical Trials: NCT02089685) (Long et al., 2017).

For melanoma brain metastases patients, Radiosurgery/ stereotactic radiotherapy in combination with immunotherapy and targeted agents has been shown to be feasible and well tolerable (Trino et al., 2017).

A phase Ib trial evaluated intratumoral SD-101, a synthetic CpG oligonucleotide that stimulates Toll-like receptor 9 (TLR9), in combination with pembrolizumab in patients with unresectable or metastatic malignant melanoma. Results indicated that the combination of pembrolizumab with intratumoral SD-101 is well tolerated and can induce immune activation at the tumor site. Combining an intratumoral TLR9 innate immune stimulant with PD-1 blockade can potentially increase clinical efficacy with minimal additional toxicity relative to PD-1 blockade alone (Clinical Trials: NCT02521870) (Ribas et al., 2018).

\section{NSCLC}

Pembrolizumab is a humanized monoclonal antibody against programmed death 1 (PD-1) that has antitumor activity in advanced non-small-cell lung cancer (NSCLC), with increased activity in tumors that express programmed death ligand 1 (PDL1). In patients with advanced NSCLC and PD-L1 expression on at least $50 \%$ of tumor cells, pembrolizumab was associated with significantly longer progression-free and OS and with fewer adverse events than was platinum-based chemotherapy (Clinical Trials: NCT02142738) (Reck et al., 2016).

More recently, pembrolizumab plus chemotherapy was shown to be an effective and tolerable first-line treatment option for patients with advanced non-squamous NSCLC. 
TABLE 2 | Nivolumab based combinational therapy.

\begin{tabular}{|c|c|c|c|c|c|c|}
\hline $\begin{array}{l}\text { Cancer } \\
\text { type }\end{array}$ & Treatment & Dose schedule & Efficacy & Adverse rate & Notes & References \\
\hline \multirow[t]{8}{*}{ Melanoma } & \multirow[t]{8}{*}{$\begin{array}{l}\text { Nivolumab } \pm \\
\text { ipilimumab }\end{array}$} & $\begin{array}{l}\mathrm{N}+\text { I q3w } \times 4 \text { doses, followed by } \mathrm{N} \\
\mathrm{q} 3 \mathrm{w} \times 4 \text { doses, continued } \mathrm{q} 12 \mathrm{w} \text { for up } \\
\text { to } 8 \text { doses } \\
\text { Escalating doses of } \mathrm{N}: 0.3,1,3,10 \mathrm{mg} / \\
\mathrm{kg} \text {; of } \mathrm{l}: 1,3,10 \mathrm{mg} / \mathrm{kg} \\
\mathrm{N} \text { q2 } \mathrm{w} \text { for up to } 48 \text { doses (previously } \\
\text { treated with ipilimumab) } \\
\text { Escalating doses of } \mathrm{N}: 1,3 \mathrm{mg} / \mathrm{kg}\end{array}$ & $\begin{array}{l}\text { All: } 40 \% \text { ORR } \\
\text { Acceptable level of } \\
\text { AEs ( } 1 \mathrm{mg} / \mathrm{kg} \mathrm{N}+ \\
3 \mathrm{mg} / \mathrm{kg} \mathrm{l}): 53 \% \\
\text { ORR } \\
20 \% \text { ORR } \\
73.4 \% \text { OS }\end{array}$ & 53\% Grade 3/4 AEs & $\begin{array}{l}\text { NCT01024231 } \\
\text { Patients with a } \\
\text { diagnosis of } \\
\text { measurable, } \\
\text { unresectable, } \\
\text { stage III or IV } \\
\text { melanoma; }\end{array}$ & $\begin{array}{l}\text { (Wolchok et al., } \\
\text { 2013) }\end{array}$ \\
\hline & & $\begin{array}{l}1 \mathrm{mg} / \mathrm{kg} \mathrm{N}+3 \mathrm{mg} / \mathrm{kg} \mathrm{I} \mathrm{q3w} \text { for } 4 \\
\text { doses, followed by } 3 \mathrm{mg} / \mathrm{kg} \mathrm{N} \text { q2w } \\
3 \mathrm{mg} / \mathrm{kg} \mathrm{I} \mathrm{q3w} \times 4 \text { doses }\end{array}$ & $\begin{array}{l}59 \% \text { ORR } \\
73.4 \% \text { OS } \\
11 \% \text { ORR } \\
63.8 \% \text { OS }\end{array}$ & $\begin{array}{l}92 \% \text { AEs } \\
94 \% \text { AEs }\end{array}$ & $\begin{array}{l}\text { NCT01927419 } \\
\text { CheckMate } 069 \\
\text { Patients with } \\
\text { unresectable stage III } \\
\text { or IV melanoma }\end{array}$ & (Hodi et al., 2016) \\
\hline & & $\begin{array}{l}1 \mathrm{mg} / \mathrm{kg} \mathrm{N}+3 \mathrm{mg} / \mathrm{kg} \mathrm{I} \mathrm{q3} \mathrm{w} \times 4 \text { doses, } \\
\text { followed by } 3 \mathrm{mg} / \mathrm{kg} \mathrm{N} \mathrm{q} 2 \mathrm{w} \\
3 \mathrm{mg} / \mathrm{kg} \mathrm{N} \mathrm{q} 2 \mathrm{w} \times 4 \text { doses }\end{array}$ & $\begin{array}{l}58 \% \text { ORR } \\
58 \% \text { OS } \\
44 \% \text { ORR } \\
52 \% \text { OS }\end{array}$ & $\begin{array}{l}\text { 59\% Grade 3/4 AEs } \\
21 \% \text { Grade 3/4 AEs }\end{array}$ & $\begin{array}{l}\text { NCT01844505 } \\
\text { CheckMate } 067 \\
\text { Patients with stage III } \\
\text { (unresectable) or stage }\end{array}$ & $\begin{array}{l}\text { (Wolchok et al., } \\
\text { 2017) }\end{array}$ \\
\hline & & $3 \mathrm{mg} / \mathrm{kg}$ I q3w $\times 4$ doses & $\begin{array}{l}19 \% \text { ORR } \\
34 \% \text { OS }\end{array}$ & 28\% Grade 3/4 AEs & IV melanoma & \\
\hline & & $\begin{array}{l}1 \mathrm{mg} / \mathrm{kg} \mathrm{N}+3 \mathrm{mg} / \mathrm{kg} \mathrm{I} \mathrm{q3w} \times 4 \text { doses, } \\
\text { followed by } 3 \mathrm{mg} / \mathrm{kg} \mathrm{N} \text { q2w } \\
3 \mathrm{mg} / \mathrm{kg} \mathrm{N} \text { q2w } \times 4 \text { doses } \\
3 \mathrm{mg} / \mathrm{kg} \mathrm{I} \mathrm{q3} \mathrm{w} \times 4 \text { doses }\end{array}$ & $\begin{array}{l}58 \% \text { ORR } \\
45 \% \text { ORR } \\
19 \% \text { ORR }\end{array}$ & $\begin{array}{l}59 \% \text { Grade 3/4 AEs } \\
22 \% \text { Grade 3/4 AEs } \\
28 \% \text { Grade 3/4 AEs }\end{array}$ & $\begin{array}{l}\text { NCT01844505 } \\
\text { Patients with } \\
\text { unresectable or stage } \\
\text { III or stage IV } \\
\text { melanoma, }\end{array}$ & (Hodi et al., 2018) \\
\hline & & $\begin{array}{l}1 \mathrm{mg} / \mathrm{kg} \mathrm{N}+3 \mathrm{mg} / \mathrm{kg} \mathrm{I} \mathrm{q3} \mathrm{w} \times 4 \text { doses, } \\
\text { followed by } 3 \mathrm{mg} / \mathrm{kg} \mathrm{N} \mathrm{q2w} \\
3 \mathrm{mg} / \mathrm{kg} \mathrm{N} \mathrm{q2w}\end{array}$ & $\begin{array}{l}58 \% \text { ORR } \\
22 \% \text { CR } \\
45 \% \text { ORR } \\
19 \% \text { CR }\end{array}$ & $\begin{array}{l}\text { 59\% Grade 3/4 AEs } \\
\text { 23\% Grade 3/4 AEs }\end{array}$ & $\begin{array}{l}\text { NCT01844505 } \\
\text { CheckMate } 067\end{array}$ & (Larkin et al., 2019) \\
\hline & & 3 mg/kg I every 3 weeks $\times 4$ doses & $\begin{array}{l}19 \% \text { ORR } \\
6 \% \text { CR }\end{array}$ & 28\% Grade 3/4 AEs & & \\
\hline & & $\begin{array}{l}1 \mathrm{mg} / \mathrm{kg} \mathrm{N}+3 \mathrm{mg} / \mathrm{kg} \text { I q3} \mathrm{w} \times 4 \text { doses, } \\
\text { then } 3 \mathrm{mg} / \mathrm{kg} \mathrm{N} \text { q2w } \\
3 \mathrm{mg} / \mathrm{kg} \mathrm{N} \text { q2w } \\
3 \mathrm{mg} / \mathrm{kg} \mathrm{N} \text { q2w (local therapy failed, } \\
\text { neurological symptoms, or } \\
\text { leptomeningeal disease) }\end{array}$ & $\begin{array}{l}46 \% \text { ORR } \\
78 \% \text { OS } \\
20 \% \text { ORR } \\
68 \% \text { OS } \\
6 \% \text { ORR } \\
44 \% \text { OS }\end{array}$ & $\begin{array}{l}\text { 97\% TRAEs } \\
\text { 54\% Grade 3/4 AEs } \\
68 \% \text { TRAEs } \\
\text { 16\% Grade 3/4 AEs } \\
50 \% \text { TRAEs } \\
\text { 13\% Grade 3/4 AEs }\end{array}$ & $\begin{array}{l}\text { NCT02374242 } \\
\text { Patients with melanoma } \\
\text { brain metastases }\end{array}$ & (Long et al., 2018) \\
\hline \multirow[t]{3}{*}{$\begin{array}{l}\text { Lung } \\
\text { cancer }\end{array}$} & $\begin{array}{l}\text { Nivoluma }+ \\
\text { standard } \\
\text { chemotherapy }\end{array}$ & 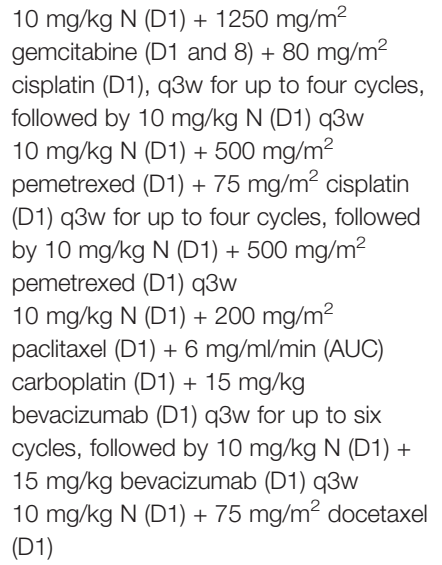 & $\begin{array}{l}50 \% \text { ORR } \\
9.63 \text { months mPFS }\end{array}$ & 100\% Grade 3/4 AEs & $\begin{array}{l}\text { JapicCTI-132071 } \\
\text { Patients with stage IIIB } \\
\text { (without indication for } \\
\text { definitive radiotherapy) } \\
\text { stage IV, or recurrent } \\
\text { NSCLC }\end{array}$ & (Kanda et al., 2016) \\
\hline & $\begin{array}{l}\text { ALT-803 + } \\
\text { nivolumab }\end{array}$ & $\begin{array}{l}3 \mathrm{mg} / \mathrm{kg} \mathrm{N} \mathrm{q} 2 \mathrm{w}+\mathrm{ALT}-803 \mathrm{q} 1 \mathrm{w} \times \text { four } \\
\text { cycles } \\
\text { Escalating dose of ALT-803: } 6,10,15 \text {, } \\
\text { or } 20 \mu \mathrm{g} / \mathrm{kg}\end{array}$ & $\begin{array}{l}\text { ORR } 29 \% \\
17.4 \text { months mPFS }\end{array}$ & - & $\begin{array}{l}\text { NCT02523469 } \\
\text { Patients with IIIB or IV } \\
\text { NSCLC (or recurrent } \\
\text { disease following } \\
\text { previous radiotherapy } \\
\text { or surgical resection) }\end{array}$ & $\begin{array}{l}\text { (Wrangle et al., } \\
\text { 2018) }\end{array}$ \\
\hline & $\begin{array}{l}\text { Nivolumab } \pm \\
\text { ipilimumab }\end{array}$ & $\begin{array}{l}1 \mathrm{mg} / \mathrm{kg} \mathrm{N}+3 \mathrm{mg} / \mathrm{kg} \mathrm{I} \mathrm{q} 3 \mathrm{w} \text { for four } \\
\text { cycles, followed by } 3 \mathrm{mg} / \mathrm{kg} \mathrm{N} \text { q2w }\end{array}$ & $46.2 \%$ ORR & - & $\begin{array}{l}\text { NCT01928394 } \\
\text { CheckMate } 032\end{array}$ & $\begin{array}{l}\text { (Hellmann et al., } \\
\text { 2018) }\end{array}$ \\
\hline
\end{tabular}

(Continued) 
TABLE 2 | Continued

\begin{tabular}{|c|c|c|c|c|c|c|}
\hline $\begin{array}{l}\text { Cancer } \\
\text { type }\end{array}$ & Treatment & Dose schedule & Efficacy & Adverse rate & Notes & References \\
\hline & & $3 \mathrm{mg} / \mathrm{kg} \mathrm{N}$ q2w & $21.3 \%$ ORR & - & $\begin{array}{l}\text { Patients with limited- or } \\
\text { extensive-stage SCLC } \\
\text { with progression after } \\
\text { at least one platinum- } \\
\text { based chemotherapy } \\
\text { regimen }\end{array}$ & \\
\hline $\begin{array}{l}\text { Metastatic } \\
\text { sarcoma }\end{array}$ & $\begin{array}{l}\text { Nivolumab } \pm \\
\text { ipilimumab }\end{array}$ & $\begin{array}{l}3 \mathrm{mg} / \mathrm{kg} \mathrm{N}+1 \mathrm{mg} / \mathrm{kg} \text { I q3w for } 4 \\
\text { doses, followed by } 3 \mathrm{mg} / \mathrm{kg} \mathrm{N} \text { q2w for } \\
\text { up to } 2 \text { years } \\
3 \mathrm{mg} / \mathrm{kg} \mathrm{N} \text { q2w, followed by } 3 \mathrm{mg} / \mathrm{kg} \mathrm{N} \\
\text { q2w for up to } 2 \text { years }\end{array}$ & $\begin{array}{l}16 \% \text { ORR } \\
4.1 \text { months mPFS } \\
5 \% \text { ORR } \\
1.7 \text { months mPFS }\end{array}$ & $26 \%$ Serious TRAEs & $\begin{array}{l}\text { NCT02500797 } \\
\text { Patients with bone or } \\
\text { soft tissue sarcoma, } \\
\text { locally advanced, } \\
\text { unresectable, or } \\
\text { metastatic sarcoma }\end{array}$ & $\begin{array}{l}\text { (D'angelo et al., } \\
\text { 2018) }\end{array}$ \\
\hline \multirow[t]{2}{*}{$\begin{array}{l}\text { Renal-cell } \\
\text { carcinoma }\end{array}$} & \multirow[t]{2}{*}{$\begin{array}{l}\text { Nivolumab + } \\
\text { ipilimumab }\end{array}$} & \multirow{2}{*}{$\begin{array}{l}3 \mathrm{mg} / \mathrm{kg} \mathrm{N}+1 \mathrm{mg} / \mathrm{kg} \mathrm{I} \mathrm{q3} \mathrm{w} \times 4 \text { doses, } \\
\text { followed by } 3 \mathrm{mg} / \mathrm{kg} \mathrm{N} \text { q2w } \\
1 \mathrm{mg} / \mathrm{kg} \mathrm{N}+3 \mathrm{mg} / \mathrm{kg} \mathrm{I} \mathrm{q3w} \times 4 \text { doses, } \\
\text { followed by } 3 \mathrm{mg} / \mathrm{kg} \mathrm{N} \text { q2w } \\
3 \mathrm{mg} / \mathrm{kg} \mathrm{N}+1 \mathrm{mg} / \mathrm{kg} \mathrm{I} \mathrm{q3w} \times 4 \text { doses, } \\
\text { followed by } 3 \mathrm{mg} / \mathrm{kg} \mathrm{N} \text { q2w } \\
50 \mathrm{mg} \text { sunitinib q1d for } 4 \text { weeks }\end{array}$} & $\begin{array}{l}40.4 \% \text { ORR } \\
67.3 \% \text { OS } \\
40.4 \% \text { ORR } \\
69.6 \% \text { OS }\end{array}$ & $\begin{array}{l}\text { 38.3\% Grade 3/4 TRAEs } \\
61.7 \% \text { Grade } 3 / 4 \text { TRAEs }\end{array}$ & $\begin{array}{l}\text { CheckMate } 016 \\
\text { Patients with advanced } \\
\text { RCC or mRCC with a } \\
\text { clear-cell component }\end{array}$ & $\begin{array}{l}\text { (Hammers et al., } \\
\text { 2017) }\end{array}$ \\
\hline & & & $\begin{array}{l}55.2 \% \text { ORR } \\
80 \% \text { OS } \\
25.5 \% \text { ORR } \\
72 \% \text { OS }\end{array}$ & $\begin{array}{l}\text { 93\% TRAEs } \\
\text { 46\% Grade 3/4 AEs } \\
\text { 97\% TRAEs } \\
63 \% \text { Grade } 3 / 4 \text { AEs }\end{array}$ & $\begin{array}{l}\text { NCT02231749 } \\
\text { Patients with advanced } \\
\text { renal-cell carcinoma } \\
\text { with a clear-cell } \\
\text { component }\end{array}$ & (Motzer et al., 2018) \\
\hline $\begin{array}{l}\text { Colorectal } \\
\text { cancer }\end{array}$ & $\begin{array}{l}\text { Nivolumab + } \\
\text { ipilimumab }\end{array}$ & $\begin{array}{l}3 \mathrm{mg} / \mathrm{kg} \mathrm{N}+1 \mathrm{mg} / \mathrm{kg} \mathrm{I} \mathrm{q3} \mathrm{w} \times 4 \text { doses, } \\
\text { followed by } 3 \mathrm{mg} / \mathrm{kg} \mathrm{N} \text { q2w }\end{array}$ & $\begin{array}{l}55 \% \text { ORR } \\
85 \% \text { OS }\end{array}$ & - & $\begin{array}{l}\text { CheckMate- } 142 \\
\text { Patients recurrent CRC } \\
\text { or } \mathrm{mCRC} \text { assessed as } \\
\mathrm{dMMR} \text { and/or MSI-H } \\
\text { per local guidelines }\end{array}$ & $\begin{array}{l}\text { (Overman et al., } \\
\text { 2018) }\end{array}$ \\
\hline
\end{tabular}

Cohort G of KEYNOTE-021 (NCT02039674) evaluated the efficacy and safety of pembrolizumab plus pemetrexedcarboplatin (PC) versus PC alone as first-line therapy for advanced nonsquamous NSCLC. At the primary analysis (median follow-up time 10.6 months), pembrolizumab significantly improved ORR and PFS; the hazard ratio (HR) for OS was 0.90 (95\% confidence interval [CI]: 0.42-1.91) (Langer et al., 2016).

The updated analysis indicated that significant improvements in PFS and ORR with pembrolizumab plus PC versus PC alone observed in the primary analysis were maintained, and the HR for OS with a 24-month median follow-up was 0.56, favoring pembrolizumab plus PC (Borghaei et al., 2019).

In patients with previously untreated metastatic nonsquamous NSCLC without EGFR or ALK mutations, the addition of pembrolizumab to standard chemotherapy of pemetrexed and a platinum-based drug resulted in significantly longer OS and PFS than chemotherapy alone (Clinical Trials: NCT02578680) (Gandhi et al., 2018).

In patients with previously untreated metastatic, squamous NSCLC (Clinical Trials: NCT02775435), the addition of pembrolizumab to chemotherapy with carboplatin plus paclitaxel or nab-paclitaxel resulted in significantly longer OS and PFS than chemotherapy alone (Paz-Ares et al., 2018).

Insinga RP et al. describe cost-effectiveness of pembrolizumab plus platinum and pemetrexed chemotherapy in metastatic, nonsquamous, NSCLC patients in the US. As a result, the addition of pembrolizumab to chemotherapy is projected to extend life expectancy to a point not previously seen in previously untreated metastatic non-squamous NSCLC. Although ICERs vary by sub-group and comparator, results suggest pembrolizumab + chemotherapy yields ICERs near, or in most cases, well below a 3-times US per capita GDP threshold of $\$ 180,000 / \mathrm{QALY}$, and may be a cost-effective first-line treatment for metastatic non-squamous NSCLC patients (Insinga et al., 2018).

\section{Renal-Cell Carcinoma}

The treatment combination of axitinib plus pembrolizumab is tolerable and shows promising antitumour activity in patients with treatment-naive advanced renal cell carcinoma (Clinical Trials: NCT02133742) (Atkins et al., 2018). In addition, among patients with previously untreated advanced renal-cell carcinoma, treatment with pembrolizumab plus axitinib resulted in significantly longer OS and PFS, as well as a higher ORR, than treatment with sunitinib (Clinical Trials: NCT02853331) (Rini et al., 2019).

\section{Advanced Solid Tumors}

Purpose Stereotactic body radiotherapy (SBRT) may stimulate innate and adaptive immunity to augment immunotherapy response. Multisite SBRT is an emerging paradigm for treating metastatic disease. Anti-PD-1-treatment outcomes may be improved with lower disease burden. A phase I study to evaluate the safety of pembrolizumab with multisite SBRT in patients with metastatic solid tumors and indicated that multisite SBRT followed by pembrolizumab was well tolerated with acceptable toxicity. Additional studies exploring the clinical benefit and predictive biomarkers of combined multisite SBRT 
and PD-1-directed immunotherapy are ongoing (Luke et al., 2018).

The phase Ib study (NCT02179918) evaluated the safety, antitumor activity, pharmacokinetics, and pharmacodynamics of utomilumab, a fully human IgG2 mAb agonist of the T-cell costimulatory receptor $4-1 \mathrm{BB} / \mathrm{CD} 137$ in combination with the humanized, PD-1-blocking IgG4 mAb pembrolizumab in patients with advanced solid tumors. Results showed that patients received combination treatment with no dose-limiting toxicities. Treatment-emergent adverse events were mostly grades 1 to 2, without any treatment-related discontinuations. 26.1\% patients had confirmed complete or partial responses (Tolcher et al., 2017).

\section{Gastric/Gastroesophageal Junction Cancer}

The multicohort, phase II, nonrandomized KEYNOTE-059 study evaluated pembrolizumab \pm chemotherapy in advanced gastric/ gastroesophageal junction cancer. In detail, in the combination therapy and monotherapy cohorts, 25 and 31 patients were enrolled; median follow-up was 13.8 months (range 1.8-24.1) and 17.5 months (range 1.7-20.7), respectively. In the combination therapy cohort, grade $3 / 4$ treatment-related adverse events occurred in 19 patients $(76.0 \%)$; none were fatal. In the monotherapy cohort, grade 3-5 treatment-related adverse events occurred in seven patients (22.6\%); one death was attributed to a treatment-related adverse event (pneumonitis). The ORR was 60.0\% [95\% confidence interval (CI), 38.7-78.9] (combination therapy) and $25.8 \%$ (95\% CI 11.9-44.6) (monotherapy). This study indicated that pembrolizumab demonstrated antitumor activity and was well tolerated as monotherapy and in combination with chemotherapy in patients with previously untreated advanced gastric/gastroesophageal junction adenocarcinoma (Bang et al., 2019).

The details for clinical trials of pembrolizumab based combinational therapy were summarized in Table 3.

\section{Atezolizumab Based Combinational Therapy NSCLC and SCLC}

Atezolizumab, which restores anticancer immunity, improved OS in patients with previously treated NSCLC and also showed clinical benefit when combined with chemotherapy as first-line treatment of NSCLC. To assess the efficacy and safety of atezolizumab plus chemotherapy versus chemotherapy alone as first-line therapy for non-squamous NSCLC, IMpower130 showed a significant and clinically meaningful improvement in OS and a significant improvement in PFS with atezolizumab plus chemotherapy, than chemotherapy as first-line treatment of patients with stage IV non-squamous NSCLC and no ALK or EGFR mutations. No new safety signals were identified. This study supports the benefit of atezolizumab, in combination with platinum-based chemotherapy, as first-line treatment of metastatic non-small-cell lung cancer (Clinical Trials: NCT02367781) (West et al., 2019).

The phase Ib clinical trial NCT01633970 involved patients with metastatic or locally advanced NSCLC $(n=30)$ who received $15 \mathrm{mg} / \mathrm{kg}$ atezolizumab at 3-week intervals combined with standard chemotherapy (carboplatin + paclitaxel, pemetrexed, or nab-paclitaxel for a total of 4-6 cycles and then maintained with atezolizumab until progression). The ORR was 67\% (18 partial responses; two complete responses) (Markham, 2016; Liu et al., 2018).

The addition of atezolizumab to chemotherapy in the firstline treatment of extensive-stage small-cell lung cancer resulted in significantly longer OS and PFS than chemotherapy alone. (Clinical Trials: NCT02763579) (Horn et al., 2018).

\section{Breast Cancer}

Atezolizumab plus nab-paclitaxel prolonged PFS among patients with metastatic triple-negative breast cancer in both the intention-to-treat population and the PD-L1-positive subgroup. Adverse events were consistent with the known safety profiles of each agent (Clinical Trials: NCT02425891) (Schmid et al., 2018).

In the phase Ib clinical trial NCT01633970, patients diagnosed with triple-negative breast cancer received atezolizumab $(800 \mathrm{mg}$ at 2-week intervals) plus nab-paclitaxel $\left(125 \mathrm{mg} / \mathrm{m}^{2}\right.$, once a week for 3 weeks in a 4-week treatment course), and five patients were evaluated for efficacy at three-month follow up (four partial responses and one complete response) (Markham, 2016; Liu et al., 2018).

\section{Renal-Cell Carcinoma}

In the phase Ib clinical trial NCT01633970, patients $(\mathrm{n}=12)$ diagnosed with metastatic renal cell carcinoma received atezolizumab (20 mg/kg) plus bevacizumab (15 mg/kg, at 3week intervals). At a minimum follow up of 2.1 months, a total of 10 evaluable patients exhibited an ORR of $40 \%$. This study indicated that atezolizumab in combination with bevacizumab enhances antigen-specific T-cell migration in metastatic renal cell carcinoma (Wallin et al., 2016).

The details for clinical trials of atezolizumab based combinational therapy were summarized in Table 4.

\section{Durvalumab Based Combinational Therapy NSCLC}

Clinical Trials NCT02000947 assess durvalumab plus tremelimumab in patients with advanced squamous or nonsquamous NSCLC. Durvalumab $20 \mathrm{mg} / \mathrm{kg}$ every 4 weeks plus tremelimumab $1 \mathrm{mg} / \mathrm{kg}$ showed a manageable tolerability profile, with antitumor activity irrespective of PD-L1 status (Antonia et al., 2016).

Clinical trial NCT02088112 evaluated the combinational therapy of durvalumab (10 mg/kg intravenously Q2W) plus gefitinib (250 mg once daily) in TKI-naive patients harboring sensitizing EGFR mutations associated with advanced NSCLC (Gibbons et al., 2016). Approximately 10 patients were assigned to group 1 and given durvalumab + gefitinib, whereas the other 10 patients of group 2 were administered gefitinib monotherapy for the first 4 weeks, followed by gefitinib plus durvalumab (Gibbons et al., 2016). The results observed grade 3-4 adverse effects, and the treatment was 
TABLE 3 | Pembrolizumab based combinational therapy.

\begin{tabular}{|c|c|c|c|c|c|c|}
\hline Cancer type & Treatment & Dose schedule & Efficacy & Adverse rate & Notes & References \\
\hline \multirow[t]{10}{*}{ Melanoma } & $\begin{array}{l}\text { Pembrolizumab } \\
+ \text { ipilimumab }\end{array}$ & $\begin{array}{l}2 \mathrm{mg} / \mathrm{kg} \mathrm{P}+1 \mathrm{mg} / \mathrm{kg} \text { I q3w } \times 4 \text { doses, } \\
\text { followed by } 2 \mathrm{mg} / \mathrm{kg} \mathrm{P} \text { q3w for up to } 2 \\
\text { years }\end{array}$ & $\begin{array}{l}61 \% \text { ORR } \\
89 \% \text { OS }\end{array}$ & $\begin{array}{l}45 \% \text { Grade } 3 / \\
4 \text { TRAEs }\end{array}$ & $\begin{array}{l}\text { NCT02089685 } \\
\text { Patients with advanced } \\
\text { melanoma }\end{array}$ & (Long et al., 2017) \\
\hline & $\begin{array}{l}\text { SD-101 + } \\
\text { pembrolizumab }\end{array}$ & $\begin{array}{l}\text { 1, 2, 4, or } 8 \text { mg SD-101 (Naive to prior } \\
\text { anti-PD-1/PD-L1 therapy) }\end{array}$ & ORR $78 \%$ & - & $\begin{array}{l}\text { NCT0252189 } \\
\text { Patients with unresectable }\end{array}$ & (Ribas et al., 2018) \\
\hline & & $\begin{array}{l}\text { 1, 2, 4, or } 8 \text { mg SD-101 (Received prior } \\
\text { anti-PD-1/PD-L1 therapy) }\end{array}$ & ORR $15 \%$ & - & $\begin{array}{l}\text { or metastatic malignant } \\
\text { melanoma }\end{array}$ & \\
\hline & $\begin{array}{l}\text { Pembrolizumab } \\
\pm \\
\text { chemotherapy }\end{array}$ & $\begin{array}{l}200 \mathrm{mg} P \text { for four cycles }+5 \mathrm{mg} / \mathrm{ml} / \mathrm{min} \\
\text { (AUC) carboplatin }+500 \mathrm{mg} / \mathrm{m}^{2} \\
\text { pemetrexed q3w, followed by } \mathrm{P} \text { for } 24 \\
\text { months + pemetrexed maintenance }\end{array}$ & $55 \%$ ORR & 93\% TRAEs & $\begin{array}{l}\text { NCT02039674 } \\
\text { Patients with } \\
\text { chemotherapy-naive, } \\
\text { stage IIIB, or IV, non- }\end{array}$ & (Langer et al., 2016) \\
\hline & & $\begin{array}{l}\text { Carboplatin + pemetrexed for four cycles, } \\
\text { followed by pemetrexed maintenance }\end{array}$ & $29 \%$ ORR & $90 \%$ TRAEs & squamous NSCLC & \\
\hline & $\begin{array}{l}\text { Pembrolizumab } \\
\pm \text { PC }\end{array}$ & $\begin{array}{l}500 \mathrm{mg} / \mathrm{m}^{2} \text { pemetrexed }+5 \mathrm{mg} / \mathrm{ml} / \mathrm{min} \\
\text { (AUC) carboplatin q3w for four cycles }+ \\
200 \mathrm{mg} P \text { q } 3 \mathrm{w} \text { for } 2 \text { years }\end{array}$ & $56.7 \%$ ORR & $16.9 \%$ TRAEs & $\begin{array}{l}\text { NCT02039674 } \\
\text { MK-3475-021/KEYNOTE- } \\
021\end{array}$ & (Borghaei et al., 2019) \\
\hline & & 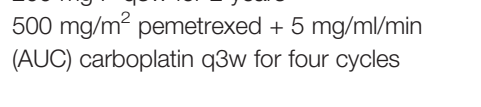 & $30.2 \%$ ORR & $12.9 \%$ TRAES & $\begin{array}{l}\text { Patients with } \\
\text { stage IIIB/IV } \\
\text { nonsquamous NSCLC }\end{array}$ & \\
\hline & $\begin{array}{l}\text { Pembrolizumab } \\
\pm \text { Pemetrexed }+ \\
\text { platinum-based } \\
\text { drug }\end{array}$ & $\begin{array}{l}\text { Pemetrexed + platinum-based drug }+200 \\
\text { mg P q3w for four cycles, followed by P for } \\
\text { up to } 35 \text { cycles + pemetrexed maintenance } \\
\text { Pemetrexed + platinum-based drug q3w } \\
\text { for four cycles, followed by pemetrexed } \\
\text { maintenance }\end{array}$ & $69.2 \%$ OS & - & $\begin{array}{l}\text { NCT02578680 } \\
\text { KEYNOTE-189 } \\
\text { Patients } \\
\text { with metastatic non- } \\
\text { squamous NSCLC }\end{array}$ & (Gandhi et al., 2018) \\
\hline & $\begin{array}{l}\text { Pembrolizumab } \\
\pm \text { carboplatin + } \\
\text { [nab]-paclitaxel }\end{array}$ & $\begin{array}{l}200 \mathrm{mg} P(\mathrm{D} 1) \text { for up to } 35 \text { cycles }+6 \mathrm{mg} / \\
\mathrm{ml} / \mathrm{min} \text { (AUC) carboplatin (D1) }+200 \mathrm{mg} / \mathrm{m}^{2} \\
\text { paclitaxel (D1) or } 100 \mathrm{mg} / \mathrm{m}^{2} \text { nab-paclitaxel } \\
\text { (D1, 8, and 15) for the first four cycles }\end{array}$ & $\begin{array}{l}15.9 \text { months } \\
\text { mOS }\end{array}$ & $\begin{array}{l}98.2 \% \text { AEs } \\
69.8 \% \text { Grade } \\
>3 \text { AEs }\end{array}$ & $\begin{array}{l}\text { NCT02775435 } \\
\text { KEYNOTE-407 } \\
\text { Patients with untreated } \\
\text { metastatic, squamous }\end{array}$ & (Paz-Ares et al., 2018) \\
\hline & & 200 mg P (D1) for up to 35 cycles & $\begin{array}{l}13.2 \text { months } \\
\text { mOS }\end{array}$ & $\begin{array}{l}97.9 \% \text { AEs } \\
68.2 \% \text { Grade } \\
\geq 3 \text { AEs }\end{array}$ & NSCLC & \\
\hline \multirow[t]{3}{*}{$\begin{array}{l}\text { Renal-cell } \\
\text { carcinoma }\end{array}$} & $\begin{array}{l}\text { Pembrolizumab } \\
+ \text { axitinib }\end{array}$ & $5 \mathrm{mg}$ axitinib q2d + 2 mg/kg P q3w & $\begin{array}{l}73 \% \text { ORR } \\
20.4 \text { months } \\
\text { mOS }\end{array}$ & $\begin{array}{l}65 \% \text { Grade } \geq \\
3 \text { AEs } \\
54 \% \text { TRAEs }\end{array}$ & $\begin{array}{l}\text { NCT02133742 } \\
\text { Patients with advanced } \\
\text { renal cell carcinoma } \\
\text { (predominantly clear cell } \\
\text { subtype) }\end{array}$ & (Atkins et al., 2018) \\
\hline & & 200 mg P q3w + 5 mg axitinib q2d & $\begin{array}{l}59.3 \% \text { ORR } \\
15.1 \text { months } \\
\text { mPFS }\end{array}$ & $\begin{array}{l}75.8 \% \text { Grade } \\
\geq 3 \text { AEs }\end{array}$ & $\begin{array}{l}\text { NCT02853331 } \\
\text { KEYNOTE-426 } \\
\text { Patients with untreated }\end{array}$ & (Rini et al., 2019) \\
\hline & & $\begin{array}{l}50 \text { mg sunitinib q1d for the first } 4 \text { weeks of } \\
\text { each } 6 \text {-week cycle }\end{array}$ & $\begin{array}{l}35.7 \% \text { ORR } \\
11.1 \text { months } \\
\text { mPFS }\end{array}$ & $\begin{array}{l}70.6 \% \text { Grade } \\
\geq 3 \text { AEs }\end{array}$ & $\begin{array}{l}\text { advanced clear-cell renal- } \\
\text { cell carcinoma }\end{array}$ & \\
\hline \multirow[t]{2}{*}{$\begin{array}{l}\text { Advanced solid } \\
\text { tumors }\end{array}$} & $\begin{array}{l}\text { SBRT + } \\
\text { pembrolizumab }\end{array}$ & SBRT + 200 mg P q3w (within 7 days) & $\begin{array}{l}\text { ORR } 13.2 \% \\
9.6 \text { months } \\
\text { mOS } \\
3.1 \text { months } \\
\text { mPFS }\end{array}$ & - & $\begin{array}{l}\text { NCT02608385 } \\
\text { Patients with metastatic } \\
\text { solid tumor previously } \\
\text { treated with standard-of- } \\
\text { care therapy }\end{array}$ & (Luke et al., 2018) \\
\hline & $\begin{array}{l}\text { Pembrolizumab } \\
\text { + utomilumab }\end{array}$ & $\begin{array}{l}2 \mathrm{mg} / \mathrm{kg} P \mathrm{q} 3 \mathrm{w}+0.45-5.0 \mathrm{mg} / \mathrm{kg} \\
\text { utomilumab }\end{array}$ & $26.1 \% \mathrm{ORR}$ & - & $\begin{array}{l}\text { NCT02179918 } \\
\text { Patients with advanced/ } \\
\text { metastatic solid tumor } \\
\text { malignancy }\end{array}$ & (Tolcher et al., 2017) \\
\hline $\begin{array}{l}\text { Gastric/ } \\
\text { gastroesophageal } \\
\text { junction cancer }\end{array}$ & $\begin{array}{l}\text { Pembrolizumab } \\
\pm \\
\text { chemotherapy }\end{array}$ & $\begin{array}{l}200 \mathrm{mg} \text { P for over } 30 \mathrm{~min} \text { infusion (D1) + } \\
80 \mathrm{mg} / \mathrm{m}^{2} \text { cisplatin (D1) for up to six cycles } \\
+800 \mathrm{mg} / \mathrm{m}^{2} 5 \text {-fluorouracil (D1-5 of each } \\
21 \text {-day cycle) for continuous infusion } \\
200 \mathrm{mg} \text { pembrolizumab for over } 30 \mathrm{~min} \\
\text { infusion (D1 of each } 21 \text {-day cycle) }\end{array}$ & $25.8 \%$ ORR & $77.4 \%$ TRAEs & $\begin{array}{l}\text { NCT02335411 } \\
\text { KEYNOTE-059 } \\
\text { Patients with recurrent or } \\
\text { metastatic G/GEJ } \\
\text { adenocarcinoma }\end{array}$ & (Bang et al., 2019) \\
\hline
\end{tabular}


TABLE 4 | Atezolizumab based combinational therapy.

\begin{tabular}{|c|c|c|c|c|c|c|}
\hline $\begin{array}{l}\text { Cancer } \\
\text { type }\end{array}$ & Treatment & Dose schedule & Efficacy & Adverse rate & Notes & References \\
\hline \multirow[t]{3}{*}{$\begin{array}{l}\text { NSCLC } \\
\text { and } \\
\text { SCLC }\end{array}$} & $\begin{array}{l}\text { Atezolizumab + } \\
\text { Chemotherapy }\end{array}$ & $\begin{array}{l}1200 \mathrm{mg} \mathrm{A} \text { q3w }+6 \mathrm{mg} / \mathrm{ml} / \mathrm{min} \text { (AUC) carboplatin } \\
\text { q3w + } 100 \mathrm{mg} / \mathrm{m}^{2} \text { nab-paclitaxel q1w } \\
6 \mathrm{mg} / \mathrm{ml} / \mathrm{min} \text { (AUC) carboplatin q3w }+100 \mathrm{mg} / \mathrm{m}^{2} \\
\text { nab-paclitaxel q1w for } 4 \text { or } 621 \text {-day cycles, } \\
\text { followed by maintenance therapy }\end{array}$ & $\begin{array}{l}18.6 \text { months mOS } \\
13.9 \text { months mOS }\end{array}$ & $\begin{array}{l}\text { 24\% Serious TRAEs } \\
\text { 13\% Serious TRAEs }\end{array}$ & $\begin{array}{l}\text { NCT02367781 } \\
\text { Patients with } \\
\text { stage IV non- } \\
\text { squamous } \\
\text { NSCLC }\end{array}$ & $\begin{array}{l}\text { West et al., } \\
\text { 2019) }\end{array}$ \\
\hline & $\begin{array}{l}\text { Atezolizumab + } \\
\text { platinum-based } \\
\text { doublet } \\
\text { chemotherapy }\end{array}$ & $\begin{array}{l}15 \mathrm{mg} / \mathrm{kg} \mathrm{A}+6 \mathrm{mg} / \mathrm{ml} \text { (AUC) carboplatin q3w + } \\
200 \mathrm{mg} / \mathrm{m}^{2} \text { paclitaxel q3w } \\
15 \mathrm{mg} / \mathrm{kg} \mathrm{A}+6 \mathrm{mg} / \mathrm{ml} \text { (AUC) carboplatin q3w + } \\
500 \mathrm{mg} / \mathrm{m}^{2} \text { pemetrexed q3w } \\
15 \mathrm{mg} / \mathrm{kg} \mathrm{A}+6 \mathrm{mg} / \mathrm{ml} \text { (AUC) carboplatin q3w + } \\
100 \mathrm{mg} / \mathrm{m}^{2} \text { nab-paclitaxel q1w }\end{array}$ & $\begin{array}{l}36 \% \text { ORR } \\
12.9 \text { months mOS } \\
68 \% \text { ORR } \\
18.9 \text { months mOS } \\
46 \% \text { ORR } \\
17 \text { months mOS }\end{array}$ & $\begin{array}{l}76 \% \text { Grade } \geq 3 \text { TRAEs } \\
52 \% \text { Grade } \geq 3 \text { TRAEs } \\
89 \% \text { Grade } \geq 3 \text { TRAEs }\end{array}$ & $\begin{array}{l}\text { NCT01633970 } \\
\text { Patients with } \\
\text { stage IIIB/IV } \\
\text { NSCLC }\end{array}$ & $\begin{array}{l}\text { (Markham, } \\
\text { 2016; Liu } \\
\text { et al., 2018) }\end{array}$ \\
\hline & $\begin{array}{l}\text { Atezolizumab + } \\
\text { Carboplatin and } \\
\text { Etoposide }\end{array}$ & $\begin{array}{l}5 \mathrm{mg} / \mathrm{ml} / \mathrm{min} \text { (AUC) carboplatin for four } 21 \text {-day } \\
\text { cycles }+100 \mathrm{mg} / \mathrm{m}^{2} \text { etoposide (D1-3 of each cycle) } \\
+1200 \mathrm{mg} \mathrm{A} \text { (D1 of each cycle) } \\
5 \mathrm{mg} / \mathrm{ml} / \mathrm{min} \text { (AUC) carboplatin for four } 21 \text {-day } \\
\text { cycles }+100 \mathrm{mg} / \mathrm{m}^{2} \text { etoposide (D1-3 of each cycle) }\end{array}$ & $\begin{array}{l}60.2 \% \text { ORR } \\
12.3 \text { months mOS } \\
64.4 \% \text { ORR } \\
10.3 \text { months mOS }\end{array}$ & $56.1 \%$ Grade 3/4 AEs & $\begin{array}{l}\text { NCT02763579 } \\
\text { Patients with } \\
\text { extensive-stage } \\
\text { SCLC }\end{array}$ & $\begin{array}{l}\text { (Horn et al., } \\
\text { 2018) }\end{array}$ \\
\hline $\begin{array}{l}\text { Breast } \\
\text { cancer }\end{array}$ & $\begin{array}{l}\text { Atezolizumab } \pm \text { nab- } \\
\text { paclitaxel }\end{array}$ & $\begin{array}{l}840 \mathrm{mg} \mathrm{A}(\mathrm{D} 1 \text { and } 15)+100 \mathrm{mg} / \mathrm{m}^{2} \text { nab-paclitaxel } \\
(\mathrm{D} 1,8 \text {, and } 15) \text { for } 28 \text {-day cycle } \\
\left.100 \mathrm{mg} / \mathrm{m}^{2} \text { nab-paclitaxel (D1, 8, and } 15\right) \text { for } 28- \\
\text { day cycle }\end{array}$ & $\begin{array}{l}56.0 \% \text { ORR } \\
21.3 \text { months mOS } \\
45.9 \% \text { ORR } \\
17.6 \text { months mOS }\end{array}$ & $\begin{array}{l}\text { 48.7\% Grade 3/4 AEs } \\
\text { 42.2\% Grade 3/4 AEs }\end{array}$ & $\begin{array}{l}\text { NCT02425891 } \\
\text { Patients with } \\
\text { metastatic TNBC }\end{array}$ & $\begin{array}{l}\text { (Schmid } \\
\text { et al., 2018) }\end{array}$ \\
\hline
\end{tabular}

discontinued in four patients (all included in arm 2). Observed partial response (PR) or complete response (CR) was $77.8 \%$ or $80 \%$, respectively, in patients belonging to group 1 and 2 (Gibbons et al., 2016).

\section{Women's Cancers}

A study of the PD-L1 inhibitor, durvalumab, in combination with a PARP inhibitor, olaparib, and a VEGFR1-3 inhibitor, cediranib, in recurrent women's cancers with biomarker analyses were conducted and results showed that the recommended phase 2 dose (RP2D) is tolerable and has preliminary activity in recurrent women's cancers (Lee J.M. et al., 2017; Zimmer et al., 2019).

A pilot study of durvalumab and tremelimumab and immunogenomic dynamics in metastatic breast cancer showed that responses are low in unselected metastatic breast cancer, however, higher rates of clinical benefit were observed in triple negative breast cancer (TNBC). This study suggested that immunogenomic dynamics may help identify phenotypes most likely to respond to immunotherapy (Santa-Maria et al., 2018).

In the NCT02484404 phase I trial, durvalumab plus olaparib resulted in higher clinical activity in patients diagnosed with triple-negative breast cancer or ovarian cancer in the absence of germline BRCA mutations (Lee J.M. et al., 2017).

In NCT02291055 phase I/II trial, the combinatorial treatment of durvalumab and axalimogene filolisbac were determined to be efficacious in previously treated patients who were diagnosed with HPV-associated cervical cancer (recurrent/metastatic) (Syed, 2017).

\section{Prostate Cancer}

In metastatic castration-resistant prostate cancer, durvalumab plus olaparib has acceptable toxicity, and the combination demonstrates efficacy, particularly in men with DNA damage repair (DDR) abnormalities (Karzai et al., 2018).

\section{Lymphoma}

The phase $1 \mathrm{~b} / 2$, multicenter, open-label study evaluated ibrutinib plus durvalumab in relapsed/refractory follicular lymphoma (FL) or diffuse large B-cell lymphoma (DLBCL). In FL, GCB DLBCL, and non-GCB DLBCL, ibrutinib plus durvalumab demonstrated similar activity to single-agent ibrutinib with the added toxicity of the PD-L1 blockade; the combination resulted in a safety profile generally consistent with those known for each individual agent (Herrera et al., 2020).

\section{Melanoma}

In the NCT02027961 phase I/II trial, durvalumab + darafenib + trametinib was administered to unresectable patients with wildtype metastatic or BRAF-mutant melanoma (Syed, 2017).

\section{Solid Tumors}

In the NCT02141347 phase I trial, the combination durvalumab plus tremelimumab resulted in early effects in Japanese patients diagnosed with advanced solid tumors (Syed, 2017).

The details for clinical trials of durvalumab based combinational therapy were summarized in Table 5.

\section{Avelumab Based Combinational Therapy Preclinical Study}

NHS-muIL12 and avelumab combination therapy enhanced antitumor efficacy relative to either monotherapy in two tumor models-BALB/c mice bearing orthotopic EMT-6 mammary tumors and $\mu \mathrm{Mt}$-mice bearing subcutaneous MC38 tumors. Most EMT-6 tumor-bearing mice treated with combination therapy had complete tumor regression. Combination therapy 
TABLE 5 | Durvalumab based combinational therapy.

\begin{tabular}{|c|c|c|c|c|c|c|}
\hline $\begin{array}{l}\text { Cancer } \\
\text { type }\end{array}$ & Treatment & Dose schedule & Efficacy & $\begin{array}{l}\text { Adverse } \\
\text { rate }\end{array}$ & Notes & References \\
\hline \multirow[t]{2}{*}{ NSCLC } & $\begin{array}{l}\text { Durvalumab + } \\
\text { tremelimumab }\end{array}$ & $\begin{array}{l}\text { D q4w } \times 13 \text { doses }+T \text { q4 } w \text { for } 6 \text { doses, } \\
\text { followed by } T \text { q12w } \times 3 \text { doses } \\
\text { Escalation dose of D: } 3,10,15,20 \mathrm{mg} / \mathrm{kg} \\
\text { Escalation dose of } \mathrm{T:} 1,3,10 \mathrm{mg} / \mathrm{kg}\end{array}$ & $\begin{array}{l}17 \% \\
\text { ORR }\end{array}$ & $\begin{array}{l}36 \% \\
\text { TRAEs }\end{array}$ & $\begin{array}{l}\text { NCT02000947 } \\
\text { Patients with locally advanced or metastatic } \\
\text { NSCLC, immunotherapy-naïve }\end{array}$ & $\begin{array}{l}\text { (Antonia } \\
\text { et al., 2016) }\end{array}$ \\
\hline & $\begin{array}{l}\text { Durvalumab + } \\
\text { gefitinib }\end{array}$ & $\begin{array}{l}10 \text { mg/kg D q2w + } 250 \text { mg gefitinib q1d } \\
250 \text { mg gefitinib q1d for } 4 \text { weeks, followed by } \\
10 \text { mg/kg D q2w + } 250 \text { mg gefitinib q1d }\end{array}$ & $\begin{array}{l}\text { ORR } \\
77.8 \% \\
\text { ORR } \\
80 \%\end{array}$ & $\begin{array}{l}100 \% \\
\text { TRAEs } \\
100 \% \\
\text { TRAES }\end{array}$ & $\begin{array}{l}\text { NCT02088112 } \\
\text { Patients harboring sensitizing EGFR mutations } \\
\text { associated with advanced NSCLC, TKI-naive }\end{array}$ & $\begin{array}{l}\text { (Gibbons } \\
\text { et al., 2016) }\end{array}$ \\
\hline $\begin{array}{l}\text { Women's } \\
\text { cancers }\end{array}$ & $\begin{array}{l}\text { Durvalumab + } \\
\text { olaparib }\end{array}$ & $\begin{array}{l}10 \mathrm{mg} / \mathrm{kg} \text { D q2w or } 1,500 \mathrm{mg} \mathrm{D} \text { q4w + olaparib } \\
\text { Escalation dose of olaparib: } 200,300 \mathrm{mg} \\
10 \mathrm{mg} / \mathrm{kg} \text { D q2w or } 1,500 \mathrm{mg} \mathrm{D} \mathrm{q4w} \mathrm{+} \\
\text { cediranib } \\
\text { Escalations dose of cediranib: } 20,30 \mathrm{mg}\end{array}$ & $\begin{array}{l}17 \% \\
\text { ORR } \\
50 \% \\
\text { ORR }\end{array}$ & $\begin{array}{l}- \\
-\end{array}$ & $\begin{array}{l}\text { NCT02484404 } \\
\text { Patients with TNBC or ovarian cancer }\end{array}$ & $\begin{array}{l}\text { (Lee J.M. } \\
\text { et al., 2017) }\end{array}$ \\
\hline Lymphoma & $\begin{array}{l}\text { Durvalumab + } \\
\text { ibrutinib }\end{array}$ & $\begin{array}{l}560 \text { mg ibrutinib q1d + } 10 \text { mg/kg D q2w for 28- } \\
\text { day cycles }\end{array}$ & $\begin{array}{l}25 \% \\
\text { ORR }\end{array}$ & $\begin{array}{l}20 \% \\
\text { TRAEs }\end{array}$ & $\begin{array}{l}\text { NCT02401048 } \\
\text { Patients with relapsed/refractory DLBCL or FL }\end{array}$ & $\begin{array}{l}\text { (Herrera } \\
\text { et al., 2020) }\end{array}$ \\
\hline
\end{tabular}

also induced the generation of tumor-specific immune memory, as demonstrated by protection against tumor rechallenge and induction of effector and memory $\mathrm{T}$ cells. Combination therapy enhanced cytotoxic NK and $\mathrm{CD}^{+}{ }^{+}$-cell proliferation and T-bet expression, whereas NHS-muIL12 monotherapy induced CD8 ${ }^{+}$ T-cell infiltration into the tumor. Combination therapy also enhanced plasma cytokine levels and stimulated expression of a greater number of innate and adaptive immune genes, compared with either monotherapy. These data indicate that combination therapy with NHS-muIL12 and avelumab increased antitumor efficacy in preclinical models, and suggest that combining NHS-IL12 and avelumab may be a promising approach to treating patients with solid tumors (Xu et al., 2017).

\section{Renal-Cell Carcinoma}

In a single-group, phase $1 \mathrm{~b}$ trial, avelumab plus axitinib resulted in objective responses in patients with advanced renal-cell carcinoma (Choueiri et al., 2018).

The next phase 3 trial involving previously untreated patients with advanced renal-cell carcinoma compared avelumab plus axitinib with the standard-of-care sunitinib. PFS was significantly longer with avelumab plus axitinib than with sunitinib among patients who received these agents as first-line treatment for advanced renal-cell carcinoma (Clinical Trials: NCT02684006) (Motzer et al., 2019).

\section{Head and Neck Cancer}

The JAVELIN Head and Neck 100 study is a multinational, Phase III, double-blind, placebo-controlled, randomized clinical trial assessing the efficacy of avelumab, a PD-L1 inhibitor, in combination with CRT compared with placebo in combination with CRT for high-risk HNSCC (Trial registration: Javelin Head and Neck 100; NCT 02952586) (Yu and Lee, 2019).

\section{Cemiplimab Based Combinational Therapy Preclinical Study}

In an engineered T cell/antigen-presenting cell (APC) bioassay, REGN3767 alone, or in combination with cemiplimab (REGN2810, human anti-PD-1 Ab), blocked inhibitory signaling to $\mathrm{T}$ cells mediated by hLAG-3/MHCII in the presence of PD-1/PD-L1. To test the in vivo activity of REGN3767 alone or in combination with cemiplimab, human PD-1×LAG-3 knock-in mice were generated, in which the extracellular domains of mouse Pdcd1 and Lag3 were replaced with their human counterparts. In these humanized mice, treatment with cemiplimab and REGN3767 showed increased efficacy in a mouse tumor model and enhanced the secretion of proinflammatory cytokines by tumor-specific T cells. The favorable pharmacokinetics and toxicology of REGN3767 in non-human primates, together with enhancement of antitumor efficacy of anti-PD-1 Ab in preclinical tumor models, supports its clinical development (Burova et al., 2019).

\section{Toripalimab Based Combinational Therapy}

A single-center, phase IB trial (NCT03086174) evaluated the safety and preliminary efficacy of toripalimab combined with the VEGF receptor inhibitor axitinib in patients with advanced melanoma, including chemotherapy-naive mucosal melanomas). 33 patients were enrolled to receive 1 or $3 \mathrm{mg} / \mathrm{kg}$ toripalimab every 2 weeks, in combination with $5 \mathrm{mg}$ axitinib twice a day, in a dose-escalation and cohort-expansion study. The results showed no dose-limiting toxicities observed, while $97 \%$ patients experienced treatmentrelated adverse events (TRAEs). The most common TRAEs were mild, while grade 3 or greater TRAEs occurred in $39.4 \%$ of patients. Among patients with chemotherapy-naive mucosal melanoma, 48.3\% patients achieved objective response, and the median PFS was 7.5 months. Although the combination therapy was tolerable and showed promising antitumor activity, due to patients enrolled in this study were all Asian, these results must be validated in a randomized phase III trial that includes a non-Asian population (Sheng et al., 2019).

\section{Camrelizumab Based Combinational Therapy}

The first-line standard of care for patients with recurrent or metastatic nasopharyngeal carcinoma are platinum-based doublet chemotherapy regimens, specially gemcitabine combined with cisplatin. Two single-arm, phase 1 trials (NCT02721589 and 
NCT03121716) were designed to evaluate the safety and preliminary anti-tumor activity of camrelizumab in combination with gemcitabine plus cisplatin for patients with recurrent or metastatic nasopharyngeal carcinoma. Camrelizumab combined with first-line standard therapy exhibited a manageable toxicity profile and promising preliminary anti-tumor activity for this disease in treatment-naive patients (Fang et al., 2018).

\section{Tislelizumab Based Combinational Therapy}

A multicentre, open-label, phase 1a/b study (NCT02660034) was designed to investigate the safety and anti-tumor effects of pamiparib, PARP $1 / 2$ inhibitor, in combination with tislelizumab. Forty-nine patients with advanced solid tumors were enrolled to determine the optimum doses for further evaluation. The recommended phase 2 dose was determined as tislelizumab $200 \mathrm{mg}$ every 3 weeks in combination with pamiparib $40 \mathrm{mg}$ twice daily. Pamiparib plus tislelizumab exhibited generally well tolerance and were associated with anti-tumor responses and clinical benefit in patients with advanced solid tumors, supporting further investigation of the combined therapy (Friedlander et al., 2019).

\section{TOXICITY AND SIDE EFFECTS CAUSED BY PD-1/PD-L1-BASED MONOTHERAPY OR COMBINATION THERAPY}

Similar to any other drug, checkpoint inhibitors provide benefits as well as risks. Generally speaking, side effects of PD-1 inhibitors are less common than those of CTLA-4 inhibitors. The spectrum of side effects caused by PD-1/PDL1 inhibitors includes gastrointestinal, hepatic, dermatologic, and endocrine events (Naidoo et al., 2016; Davis et al., 2017). It is usually recommended that patients with grade 2 toxicity should refrain from receiving checkpoint inhibitors transiently. For patients exhibiting grade 3 or higher adverse effects, treatment should be terminated and systemic corticosteroids should be given ( 1 to $2 \mathrm{mg} / \mathrm{kg}$ or equivalent) daily (Naidoo et al., 2016; Davis et al., 2017).

Data from mouse gene knockout studies indicated that blocking the $\mathrm{PD}-1 / \mathrm{PD}-\mathrm{L} 1$ pathway results in relatively low incidence of autoimmune reactions that can be managed with immune suppression or supportive care. Toxicological studies involving monkeys indicated gastrointestinal toxicity may reach grades 3 to 4 after application of nivolumab and ipilimumab (Sznol, 2014). Toxicities due to combinational treatment of nivolumab + ipilimumab are similar to that generated using ipilimumab alone. In return for high rates of activity and efficacy, high rates of reversible autoimmune adverse events of grade 3 to 4 caused by combination regimens could be tolerated if toxicities are reversible with acceptable morbidity (Sznol, 2014). Combining anti-PD-1/PD-L1 inhibitors with chemotherapeutic agents was reported in quite a few clinical trials. There was a single-center phase Ib study investigating the tolerability and safety of nivolumab combined with standard chemotherapy in patients with NSCLC. Skin toxicities and hepatic toxicities were more frequently than chemotherapy or nivolumab alone, they were mild and intervention with systemic corticosteroids was not needed. Only two patients with interstitial lung disease were resolved by systemic corticosteroids, which happened in two patients several months after the start of treatment. It suggests that combination therapy with nivolumab and standard chemotherapy strengthens the anti-tumor activity of each monotherapy (Kanda et al., 2016).

Thyroid disorders are one of the most common adverse events caused by anti-PD-1 monotherapy or combinatorial therapy of antiCTLA-4 plus anti-PD-1 (Lee H. et al., 2017). Studies comparing the prevalence of drug-related thyroid disorders due to monotherapy or combination therapy have been performed. The dynamic evolution of thyroid disorders has also been assessed in 45 patients who received anti-PD-1 monotherapy or anti-CTLA-4/anti-PD-1 combinatorial therapy. Results indicate that thyrotoxicosis or hypothyroidism are the initial form of thyroid disorders (Lee $\mathrm{H}$. et al., 2017). Thyrotoxicosis occurs in most of the treated patients, with a prevalence of $93 \%$ for combination therapy and $56 \%$ for monotherapy. Additionally, the onset pattern of the thyroid disorder differs significantly between these two groups $(p=0.01)$. Subsequently, $76 \%$ and $90 \%$ of thyrotoxicosis shifted into hypothyroidism in patients of combination and monotherapy groups, respectively (Lee $H$. et al., 2017). The median time for onset of thyrotoxicosis and hypothyroidism was 31 and 68 days after first treatment, and 21 and 63 days for monotherapy groups and combination therapy, respectively. The median time was 42 days for the transition from thyrotoxicosis to hypothyroidism in both groups (Lee et al., 2017).

The most common side effects include immune-related and were observed in about $60 \%$ of patients enrolled in phase II and III studies. These side effects were mainly low grade and the majority involved skin conditions such as pruritus and rash or GI conditions, including diarrhea and colitis (Weinstock et al., 2017).

\section{PROSPECTS}

Immunotherapy based on PD-1/PD-L1 has revealed its efficacy in melanoma, NSCLC, gastric cancer, as well as head and neck cancer. The frequency of side effects of PD-1/PD-L1 therapy due to immune suppression is relatively lower than using traditional cancer therapy and are better tolerated. However, due to the immunomodulating nature of the mAbs, the measurement of the biological activities (release or stability test) made a great problem in quality control laboratories (Wang et al., 2017). As therapeutic antibodies, the limited half-life and multipledosages-caused immunogenicity, which might induce overactivity of immune system, were inevitably emerged, some small-molecule immune checkpoint inhibitors to avoid these shortcomings are under developing (Lee et al., 2016; MagieraMularz et al., 2017; Li and Tian, 2019). The above factors made these drugs a high cost for biopharmaceutical industrials, which is not conducive to benefit more patients (Kandolf Sekulovic et al., 2017; Ward et al., 2017). 
Despite some disadvantages, checkpoint inhibitors possess a great prospect. The recent findings suggest that PD-1/PD-L1 inhibitors may be combined with other immunotherapies or traditional treatments to enhance efficacy relative to that using PD-1/PD-L1 therapy alone, which always exhibit higher response rates, reducing adverse reaction and drug resistance (Li J. et al., 2019; Zhang et al., 2019; Li et al., 2020; Shao et al., 2020; Sonpavde et al., 2020; Wan et al., 2020; Weiss et al., 2020; Zhang et al., 2020). Some researchers have shown the prospects of anti-PD-L1 and antiCTLA-4 combination therapy, which revealed PD-L1:CD80 (CTLA-4 ligand) cis-heterodimerization inhibited both PD-L1: PD-1 and CD80:CTLA-4 interactions. Therefore, exploration of the efficacy and mechanism of co-blockade of PD-L1 and CTLA-4 is promising (Sugiura et al., 2019; Zhao et al., 2019). The emerging nanovaccine was reported to profoundly potentiate the immunogenicity of the neoantigen, enhancing responsiveness $(\mathrm{Ni}$ et al., 2020). Furthermore, some studies reveal that angiotensinconverting enzyme 2 (ACE2) expression is increased after interleukin (IL)-1 $\beta$ treatment (Clarke et al., 2014), blockade of IL$1 \beta$ synergized with blockade of PD-1 can inhibit tumor growth (Tian et al., 2020). This correlation can provide new ideas for antiPD-1/PD-L1 therapy (Sui et al., 2014). Above all, the combination

\section{REFERENCES}

Antonia, S., Goldberg, S. B., Balmanoukian, A., Chaft, J. E., Sanborn, R. E., Gupta, A., et al. (2016). Safety and antitumour activity of durvalumab plus tremelimumab in non-small cell lung cancer: a multicentre, phase $1 \mathrm{~b}$ study. Lancet Oncol. 17, 299-308. doi: 10.1016/S1470-2045(15)00544-6

Atkins, M. B., Plimack, E. R., Puzanov, I., Fishman, M. N., Mcdermott, D. F., Cho, D. C., et al. (2018). Axitinib in combination with pembrolizumab in patients with advanced renal cell cancer: a non-randomised, open-label, dose-finding, and dose-expansion phase 1b trial. Lancet Oncol. 19, 405-415. doi: 10.1016/ S1470-2045(18)30081-0

Bang, Y., Kang, Y., Catenacci, D. V., Muro, K., Fuchs, C. S., Geva, R., et al. (2019). Pembrolizumab alone or in combination with chemotherapy as first-line therapy for patients with advanced gastric or gastroesophageal junction adenocarcinoma: results from the phase II nonrandomized KEYNOTE-059 study. Gastric Cancer 22, 828-837. doi: 10.1007/s10120-018-00909-5

Blank, C., Brown, I., Peterson, A. C., Spiotto, M., Iwai, Y., Honjo, T., et al. (2004). PD-L1/B7H-1 inhibits the effector phase of tumor rejection by $\mathrm{T}$ cell receptor (TCR) transgenic CD8+ T cells. Cancer Res. 64, 1140-1145. doi: 10.1158/00085472.CAN-03-3259

Borghaei, H., Langer, C. J., Gadgeel, S., Papadimitrakopoulou, V. A., Patnaik, A., Powell, S. F., et al. (2019). 24-Month Overall Survival from KEYNOTE-021 Cohort G: Pemetrexed and Carboplatin with or without Pembrolizumab as First-Line Therapy for Advanced Nonsquamous Non-Small Cell Lung Cancer. J. Thorac. Oncol. 14, 124-129. doi: 10.1016/j.jtho.2018.08.004

Burova, E., Hermann, A., Dai, J., Ullman, E., Halasz, G., Potocky, T., et al. (2019). Preclinical Development of the Anti-LAG-3 Antibody REGN3767: Characterization and Activity in Combination with the Anti-PD-1 Antibody Cemiplimab in Human PD-1xLAG-3-Knockin Mice. Mol. Cancer Ther. 18, 2051-2062. doi: 10.1158/1535-7163.MCT-18-1376

Butte, M. J., Keir, M. E., Phamduy, T. B., Sharpe, A. H., and Freeman, G. J. (2007). Programmed death-1 ligand 1 interacts specifically with the B7-1 costimulatory molecule to inhibit $\mathrm{T}$ cell responses. Immunity 27, 111-122. doi: 10.1016/j.immuni.2007.05.016

Cao, G., Xiao, Z., and Yin, Z. (2019). Normalization cancer immunotherapy: blocking Siglec-15! Signal Transduct. Target. Ther. 4, 10. doi: 10.1038/s41392019-0045-x therapy using PD-1/PD-L1 may pave the way for a new era for cancer immunotherapy.

\section{AUTHOR CONTRIBUTIONS}

L-WF conceived the review. J-YZ and Y-YY searched the literature and drafted the manuscript. J-JL revised literature. RA edited the manuscript. All authors approved the final version of the manuscript.

\section{FUNDING}

This work was supported by National Natural Science Foundation of China (81773888, U1903126 and 81902152), Natural Science Foundation of Guangdong Province (2020A1515010605), Fund of Guangzhou Science and Technology Program (201707010048), Open Funds of State Key Laboratory of Oncology in South China (HN2018-06), the Fund of Shanxi Province Higher Education Technology Innovation Project (2019L0753).

Choueiri, T. K., Larkin, J., Oya, M., Thistlethwaite, F., Martignoni, M., Nathan, P., et al. (2018). Preliminary results for avelumab plus axitinib as first-line therapy in patients with advanced clear-cell renal-cell carcinoma (JAVELIN Renal 100): an open-label, dose-finding and dose-expansion, phase $1 \mathrm{~b}$ trial. Lancet Oncol. 19, 451-460. doi: 10.1016/S1470-2045(18)30107-4

Clarke, N. E., Belyaev, N. D., Lambert, D. W., and Turner, A. J. (2014). Epigenetic regulation of angiotensin-converting enzyme 2 (ACE2) by SIRT1 under conditions of cell energy stress. Clin. Sci. 126, 507-516. doi: 10.1042/ CS20130291

D'angelo, S. P., Mahoney, M. R., Van Tine, B. A., Atkins, J., Milhem, M. M., Jahagirdar, B. N., et al. (2018). Nivolumab with or without ipilimumab treatment for metastatic sarcoma (Alliance A091401): two open-label, noncomparative, randomised, phase 2 trials. Lancet Oncol. 19, 416-426. doi: 10.1016/S1470-2045(18)30006-8

Davis, K. L., Agarwal, A. M., and Verma, A. R. (2017). Checkpoint inhibition in pediatric hematologic malignancies. Pediatr. Hematol. Oncol. 34, 379-394. doi: 10.1080/08880018.2017.1383542

Day, C. L., Kaufmann, D. E., Kiepiela, P., Brown, J. A., Moodley, E. S., Reddy, S., et al. (2006). PD-1 expression on HIV-specific T cells is associated with T-cell exhaustion and disease progression. Nature 443, 350-354. doi: 10.1038/nature05115

Fang, W., Yang, Y., Ma, Y., Hong, S., Lin, L., He, X., et al. (2018). Camrelizumab (SHR-1210) alone or in combination with gemcitabine plus cisplatin for nasopharyngeal carcinoma: results from two single-arm, phase 1 trials. Lancet Oncol. 19, 1338-1350. doi: 10.1016/S1470-2045(18)30495-9

Friedlander, M., Meniawy, T., Markman, B., Mileshkin, L., Harnett, P., Millward, M., et al. (2019). Pamiparib in combination with tislelizumab in patients with advanced solid tumours: results from the dose-escalation stage of a multicentre, open-label, phase 1a/b trial. Lancet Oncol. 20, 1306-1315. doi: 10.1016/S1470-2045(19)30396-1

Gandhi, L., Rodríguez-Abreu, D., Gadgeel, S., Esteban, E., Felip, E., De Angelis, F., et al. (2018). Pembrolizumab plus Chemotherapy in Metastatic Non-SmallCell Lung Cancer. N. Engl. J. Med. 378, 2078-2092. doi: 10.1056/ NEJMoa1801005

Gibbons, D. L., Chow, L. Q., Kim, D. W., Kim, S. W., Yeh, T., Song, X., et al. (2016). 57O Efficacy, safety and tolerability of MEDI4736 (durvalumab [D]), a human IgG1 anti-programmed cell death-ligand-1 (PD-L1) antibody, combined with gefitinib $(\mathrm{G})$ : A phase I expansion in TKI-naïve patients 
(pts) with EGFR mutant NSCLC. J. Thorac. Oncol. 11, S79. doi: 10.1016/S15560864(16)30171-X

Gourd, E. (2018). Nivolumab plus ipilimumab in metastatic colorectal cancer. Lancet Oncol. 19, e139. doi: 10.1016/S1470-2045(18)30067-6

Hammers, H. J., Plimack, E. R., Infante, J. R., Rini, B. I., Mcdermott, D. F., Lewis, L. D., et al. (2017). Safety and Efficacy of Nivolumab in Combination With Ipilimumab in Metastatic Renal Cell Carcinoma: The CheckMate 016 Study. J. Clin. Oncol. 35, 3851-3858. doi: 10.1200/JCO.2016.72.1985

Hanahan, D., and Weinberg, R. A. (2011). Hallmarks of cancer: the next generation. Cell 144, 646-674. doi: 10.1016/j.cell.2011.02.013

Hellmann, M. D., Callahan, M. K., Awad, M. M., Calvo, E., Ascierto, P. A., Atmaca, A., et al. (2018). Tumor Mutational Burden and Efficacy of Nivolumab Monotherapy and in Combination with Ipilimumab in Small-Cell Lung Cancer. Cancer Cell 33, 853-861.e854. doi: 10.1016/j.ccell.2018.04.001

Herbst, R. S., Soria, J. C., Kowanetz, M., Fine, G. D., Hamid, O., Gordon, M. S., et al. (2014). Predictive correlates of response to the anti-PD-L1 antibody MPDL3280A in cancer patients. Nature 515, 563-567. doi: 10.1038/ nature14011

Herrera, A. F., Moskowitz, A. J., Bartlett, N. L., Vose, J. M., Ramchandren, R., Feldman, T. A., et al. (2018). Interim results of brentuximab vedotin in combination with nivolumab in patients with relapsed or refractory Hodgkin lymphoma. Blood 131, 1183-1194. doi: 10.1182/blood-2017-10-811224

Herrera, A. F., Goy, A., Mehta, A., Ramchandren, R., Pagel, J. M., Svoboda, J., et al. (2020). Safety and activity of ibrutinib in combination with durvalumab in patients with relapsed or refractory follicular lymphoma or diffuse large B-cell lymphoma. Am. J. Hematol. 95, 18-27. doi: 10.1002/ajh.25659

Hodi, F. S., Chesney, J., Pavlick, A. C., Robert, C., Grossmann, K. F., Mcdermott, D. F., et al. (2016). Combined nivolumab and ipilimumab versus ipilimumab alone in patients with advanced melanoma: 2 -year overall survival outcomes in a multicentre, randomised, controlled, phase 2 trial. Lancet Oncol. 17, 15581568. doi: 10.1016/S1470-2045(16)30366-7

Hodi, F. S., Chiarion-Sileni, V., Gonzalez, R., Grob, J.-J., Rutkowski, P., Cowey, C. L., et al. (2018). Nivolumab plus ipilimumab or nivolumab alone versus ipilimumab alone in advanced melanoma (CheckMate 067): 4-year outcomes of a multicentre, randomised, phase 3 trial. Lancet Oncol. 19, 1480-1492. doi: 10.1016/S1470-2045(18)30700-9

Homet Moreno, B., Parisi, G., Robert, L., and Ribas, A. (2015). Anti-PD-1 therapy in melanoma. Semin. Oncol. 42, 466-473. doi: 10.1053/j.seminoncol.2015. 02.008

Horn, L., Mansfield, A. S., Szczęsna, A., Havel, L., Krzakowski, M., Hochmair, M. J., et al. (2018). First-Line Atezolizumab plus Chemotherapy in Extensive-Stage Small-Cell Lung Cancer. N. Engl. J. Med. 379, 2220-2229. doi: 10.1056/ NEJMoa1809064

Huang, L., and Fu, L. (2015). Mechanisms of resistance to EGFR tyrosine kinase inhibitors. Acta Pharm. Sin. B. 5, 390-401. doi: 10.1016/j.apsb.2015.07.001

Huang, W., Yan, Y., Liu, Y., Lin, M., Ma, J., Zhang, W., et al. (2020). Exosomes with low miR-34c-3p expression promote invasion and migration of non-small cell lung cancer by upregulating integrin $\alpha 2 \beta 1$. Signal Transduct. Target. Ther. 5 (1), 39. doi: 10.1038/s41392-020-0133-y

Insinga, R. P., Vanness, D. J., Feliciano, J. L., Vandormael, K., Traore, S., and Burke, T. (2018). Cost-effectiveness of pembrolizumab in combination with chemotherapy in the 1st line treatment of non-squamous NSCLC in the US. J. Med. Econ. 21, 1191-1205. doi: 10.1080/13696998.2018.1521416

Iwai, Y., Ishida, M., Tanaka, Y., Okazaki, T., Honjo, T., and Minato, N. (2002). Involvement of PD-L1 on tumor cells in the escape from host immune system and tumor immunotherapy by PD-L1 blockade. Proc. Natl. Acad. Sci. U. S. A. 99, 12293-12297. doi: 10.1073/pnas.192461099

Jiang, L., Wang, P., Sun, Y. J., and Wu, Y. J. (2019). Ivermectin reverses the drug resistance in cancer cells through EGFR/ERK/Akt/NF-kappaB pathway. J. Exp. Clin. Cancer Res. 38, 265. doi: 10.1186/s13046-019-1251-7

Kamta, J., Chaar, M., Ande, A., Altomare, D. A., and Ait-Oudhia, S. (2017). Advancing Cancer Therapy with Present and Emerging Immuno-Oncology Approaches. Front. Oncol. 7, 64. doi: 10.3389/fonc.2017.00064

Kanda, S., Goto, K., Shiraishi, H., Kubo, E., Tanaka, A., Utsumi, H., et al. (2016). Safety and efficacy of nivolumab and standard chemotherapy drug combination in patients with advanced non-small-cell lung cancer: a four arms phase Ib study. Ann. Oncol. 27, 2242-2250. doi: 10.1093/annonc/ mdw416
Kandolf Sekulovic, L., Peris, K., Hauschild, A., Stratigos, A., Grob, J. J., Nathan, P., et al. (2017). More than 5000 patients with metastatic melanoma in Europe per year do not have access to recommended first-line innovative treatments. Eur. J. Cancer 75, 313-322. doi: 10.1016/j.ejca.2017.01.012

Karzai, F., Vanderweele, D., Madan, R. A., Owens, H., Cordes, L. M., Hankin, A., et al. (2018). Activity of durvalumab plus olaparib in metastatic castrationresistant prostate cancer in men with and without DNA damage repair mutations. J. Immunother. Cancer 6, 141. doi: 10.1186/s40425-018-0463-2

Kathawala, R. J., Gupta, P., Ashby, C. R.Jr., and Chen, Z. S. (2015). The modulation of $\mathrm{ABC}$ transporter-mediated multidrug resistance in cancer: a review of the past decade. Drug Resist. Updat. 18, 1-17. doi: 10.1016/j.drup.2014.11.002

Langer, C. J., Gadgeel, S. M., Borghaei, H., Papadimitrakopoulou, V. A., Patnaik, A., Powell, S. F., et al. (2016). Carboplatin and pemetrexed with or without pembrolizumab for advanced, non-squamous non-small-cell lung cancer: a randomised, phase 2 cohort of the open-label KEYNOTE-021 study. Lancet Oncol. 17, 1497-1508. doi: 10.1016/S1470-2045(16)30498-3

Larkin, J., Chiarion-Sileni, V., Gonzalez, R., Grob, J. J., Rutkowski, P., Lao, C. D., et al. (2019). Five-Year Survival with Combined Nivolumab and Ipilimumab in Advanced Melanoma. N. Engl. J. Med. 381, 1535-1546. doi: 10.1056/ NEJMoa1910836

Lee, J. Y., Lee, H. T., Shin, W., Chae, J., Choi, J., Kim, S. H., et al. (2016). Structural basis of checkpoint blockade by monoclonal antibodies in cancer immunotherapy. Nat. Commun. 7, 13354. doi: 10.1038/ncomms13354

Lee, H., Hodi, F. S., Giobbie-Hurder, A., Ott, P. A., Buchbinder, E. I., Haq, R., et al. (2017). Characterization of Thyroid Disorders in Patients Receiving Immune Checkpoint Inhibition Therapy. Cancer Immunol. Res. 5, 1133-1140. doi: 10.1158/2326-6066.cir-17-0208

Lee, J. M., Cimino Mathews, A., Peer, C. J., Zimmer, A., Lipkowitz, S., Annunziata, C. M., et al. (2017). Safety and Clinical Activity of the Programmed DeathLigand 1 Inhibitor Durvalumab in Combination With Poly (ADP-Ribose) Polymerase Inhibitor Olaparib or Vascular Endothelial Growth Factor Receptor 1-3 Inhibitor Cediranib in Women's Cancers: A Dose-Escalation, Phase I Study. J. Clin. Oncol. 35, 2193-2202. doi: 10.1200/JCO.2016.72.1340

Li, K., and Tian, H. (2019). Development of small-molecule immune checkpoint inhibitors of PD-1/PD-L1 as a new therapeutic strategy for tumour immunotherapy. J. Drug Target 27, 244-256. doi: 10.1080/1061186X. 2018.1440400

Li, D., Li, X., Zhou, W., Huang, Y., Liang, X., Jiang, L., et al. (2019). Genetically engineered $\mathrm{T}$ cells for cancer immunotherapy. Signal Transduct. Target. Ther. 4, 35. doi: 10.1038/s41392-019-0070-9

Li, J., Huang, J., Jiang, Z., Li, R., Sun, A., Lai-Han Leung, E., et al. (2019). Current Clinical Progress of PD-1/PD-L1 Immunotherapy and Potential Combination Treatment in Non-Small Cell Lung Cancer. Integr. Cancer Ther. 18, 1534735419890020. doi: $10.1177 / 1534735419890020$

Li, X., Wang, M., and Xiang, R. (2019). Clonal replacement of novel T cells: a new phenomenon in the tumor microenvironment following PD-1 blockade. Signal Transduction Target. Ther. 4, 43. doi: 10.1038/s41392-019-0077-2

Li, T., Hu, Z., Wang, C., Yang, J., Zeng, C., Fan, R., et al. (2020). PD-L1-targeted microbubbles loaded with docetaxel produce a synergistic effect for the treatment of lung cancer under ultrasound irradiation. Biomater. Sci. 8 (5), 1418-1430. doi: 10.1039/c9bm01575b

Lin, M., Bi, H., Yan, Y., Huang, W., Zhang, G., Zhang, G., et al. (2017a). Parthenolide suppresses non-small cell lung cancer GLC-82 cells growth via B-Raf/MAPK/Erk pathway. Oncotarget 8, 23436-23447. doi: 10.18632/ oncotarget.15584

Lin, M., Tang, S., Zhang, C., Chen, H., Huang, W., Liu, Y., et al. (2017b). Euphorbia factor L2 induces apoptosis in A549 cells through the mitochondrial pathway. Acta Pharm. Sin. B. 7, 59-64. doi: 10.1016/ j.apsb.2016.06.008

Liu, S. V., Camidge, D. R., Gettinger, S. N., Giaccone, G., Heist, R. S., Hodi, F. S., et al. (2018). Long-term survival follow-up of atezolizumab in combination with platinum-based doublet chemotherapy in patients with advanced nonsmall-cell lung cancer. Eur. J. Cancer 101, 114-122. doi: 10.1016/ j.ejca.2018.06.033

Liu, X. L., Wang, B. B., Wang, Y., Wang, Y. X., Yang, C. H., Tan, C., et al. (2019). Unbiased screening reveals that blocking exportin 1 overcomes resistance to PI3K $\alpha$ inhibition in breast cancer. Signal Transduct. Target. Ther. 4, 49. doi: 10.1038/s41392-019-0085-2 
Long, G. V., Atkinson, V., Cebon, J. S., Jameson, M. B., Fitzharris, B. M., Mcneil, C. M., et al. (2017). Standard-dose pembrolizumab in combination with reduced-dose ipilimumab for patients with advanced melanoma (KEYNOTE-029): an open-label, phase 1b trial. Lancet Oncol. 18, 1202-1210. doi: 10.1016/S1470-2045(17)30428-X

Long, G. V., Atkinson, V., Lo, S., Sandhu, S., Guminski, A. D., Brown, M. P., et al. (2018). Combination nivolumab and ipilimumab or nivolumab alone in melanoma brain metastases: a multicentre randomised phase 2 study. Lancet Oncol. 19, 672-681. doi: 10.1016/S1470-2045(18)30139-6

Luke, J. J., Lemons, J. M., Karrison, T. G., Pitroda, S. P., Melotek, J. M., Zha, Y., et al. (2018). Safety and Clinical Activity of Pembrolizumab and Multisite Stereotactic Body Radiotherapy in Patients With Advanced Solid Tumors. J. Clin. Oncol. 36, 1611-1618. doi: 10.1200/JCO.2017.76.2229

Magiera-Mularz, K., Skalniak, L., Zak, K. M., Musielak, B., Rudzinska-Szostak, E., Berlicki, Ł., et al. (2017). Bioactive Macrocyclic Inhibitors of the PD-1/PD-L1 Immune Checkpoint. Angew. Chem. Int. Ed. Engl. 56, 13732-13735. doi: 10.1002/anie.201707707

Markham, A. (2016). Atezolizumab: First Global Approval. Drugs 76, 1227-1232. doi: $10.1007 / s 40265-016-0618-8$

Motzer, R. J., Tannir, N. M., Mcdermott, D. F., Arén Frontera, O., Melichar, B., Choueiri, T. K., et al. (2018). Nivolumab plus Ipilimumab versus Sunitinib in Advanced Renal-Cell Carcinoma. N. Engl. J. Med. 378, 1277-1290. doi: 10.1056/NEJMoa1712126

Motzer, R. J., Penkov, K., Haanen, J., Rini, B., Albiges, L., Campbell, M. T., et al. (2019). Avelumab plus Axitinib versus Sunitinib for Advanced Renal-Cell Carcinoma. N. Engl. J. Med. 380, 1103-1115. doi: 10.1056/NEJMoa1816047

Naidoo, J., Page, D. B., Li, B. T., Connell, L. C., Schindler, K., Lacouture, M. E., et al. (2016). Toxicities of the anti-PD-1 and anti-PD-L1 immune checkpoint antibodies. Ann. Oncol. 27, 1362. doi: 10.1093/annonc/mdw141

Ni, Q., Zhang, F., Liu, Y., Wang, Z., Yu, G., Liang, B., et al. (2020). A bi-adjuvant nanovaccine that potentiates immunogenicity of neoantigen for combination immunotherapy of colorectal cancer. Sci. Adv. 6, eaaw6071 doi: 10.1126/ sciadv.aaw6071

Okazaki, T., and Honjo, T. (2007). PD-1 and PD-1 ligands: from discovery to clinical application. Int. Immunol. 19, 813-824. doi: 10.1093/intimm/dxm057

Oshima, Y., Tanimoto, T., Yuji, K., and Tojo, A. (2018). EGFR-TKI-Associated Interstitial Pneumonitis in Nivolumab-Treated Patients With Non-Small Cell Lung Cancer. JAMA Oncol. 4, 1112-1115. doi: 10.1001/jamaoncol.2017.4526

Overman, M. J., Lonardi, S., Wong, K. Y. M., Lenz, H.-J., Gelsomino, F., Aglietta, M., et al. (2018). Durable Clinical Benefit With Nivolumab Plus Ipilimumab in DNA Mismatch Repair-Deficient/Microsatellite InstabilityHigh Metastatic Colorectal Cancer. J. Clin. Oncol. 36, 773-779. doi: 10.1200/ JCO.2017.76.9901

Paz-Ares, L., Luft, A., Vicente, D., Tafreshi, A., Gümüş, M., Mazières, J., et al. (2018). Pembrolizumab plus Chemotherapy for Squamous Non-Small-Cell Lung Cancer. N. Engl. J. Med. 379, 2040-2051. doi: 10.1056/NEJMoa1810865

Pico De Coaña, Y., Choudhury, A., and Kiessling, R. (2015). Checkpoint blockade for cancer therapy: revitalizing a suppressed immune system. Trends Mol. Med. 21, 482-491. doi: 10.1016/j.molmed.2015.05.005

Postow, M. A., Chesney, J., Pavlick, A. C., Robert, C., Grossmann, K., Mcdermott, D., et al. (2015). Nivolumab and ipilimumab versus ipilimumab in untreated melanoma. N. Engl. J. Med. 372, 2006-2017. doi: 10.1056/ NEJMoa1414428

Qin, Q., Nan, X., Miller, T., Fisher, R., Teh, B., Pandita, S., et al. (2018). Complete Local and Abscopal Responses from a Combination of Radiation and Nivolumab in Refractory Hodgkin's Lymphoma. Radiat. Res. 190, 322-329. doi: $10.1667 /$ RR15048.1

Quezada, S. A., and Peggs, K. S. (2013). Exploiting CTLA-4, PD-1 and PD-L1 to reactivate the host immune response against cancer. Br. J. Cancer 108, 15601565. doi: 10.1038/bjc.2013.117

Quigley, M., Pereyra, F., Nilsson, B., Porichis, F., Fonseca, C., Eichbaum, Q., et al. (2010). Transcriptional analysis of HIV-specific CD8+ T cells shows that PD-1 inhibits T cell function by upregulating BATF. Nat. Med. 16, 1147-1151. doi: $10.1038 / \mathrm{nm} .2232$

Rahimi Kalateh Shah Mohammad, G., Ghahremanloo, A., Soltani, A., Fathi, E., and Hashemy, S. I. (2020). Cytokines as potential combination agents with PD1/PD-L1 blockade for cancer treatment. J. Cell. Physiol. 235 (7-8), 5449-5460. doi: $10.1002 /$ jcp.29491
Reck, M., Rodríguez-Abreu, D., Robinson, A. G., Hui, R., Csőszi, T., Fülöp, A., et al. (2016). Pembrolizumab versus Chemotherapy for PD-L1-Positive NonSmall-Cell Lung Cancer. N. Engl. J. Med. 375, 1823-1833. doi: 10.1056/ NEJMoa1606774

Ribas, A., Medina, T., Kummar, S., Amin, A., Kalbasi, A., Drabick, J. J., et al. (2018). SD-101 in Combination with Pembrolizumab in Advanced Melanoma: Results of a Phase Ib, Multicenter Study. Cancer Discovery 8, 1250-1257. doi: 10.1158/2159-8290.CD-18-0280

Rini, B. I., Plimack, E. R., Stus, V., Gafanov, R., Hawkins, R., Nosov, D., et al. (2019). Pembrolizumab plus Axitinib versus Sunitinib for Advanced Renal-Cell Carcinoma. N. Engl. J. Med. 380, 1116-1127. doi: 10.1056/NEJMoa1816714

Sanmamed, M. F., and Chen, L. (2018). A Paradigm Shift in Cancer Immunotherapy: From Enhancement to Normalization. Cell 175, 313-326. doi: 10.1016/j.cell.2018.09.035

Santa-Maria, C. A., Kato, T., Park, J.-H., Kiyotani, K., Rademaker, A., Shah, A. N., et al. (2018). A pilot study of durvalumab and tremelimumab and immunogenomic dynamics in metastatic breast cancer. Oncotarget 9, 1898518996. doi: 10.18632/oncotarget. 24867

Schmid, P., Adams, S., Rugo, H. S., Schneeweiss, A., Barrios, C. H., Iwata, H., et al. (2018). Atezolizumab and Nab-Paclitaxel in Advanced Triple-Negative Breast Cancer. N. Engl. J. Med. 379, 2108-2121. doi: 10.1056/NEJMoa1809615

Selby, M. J., Engelhardt, J. J., Johnston, R. J., Lu, L. S., Han, M., Thudium, K., et al. (2016). Preclinical Development of Ipilimumab and Nivolumab Combination Immunotherapy: Mouse Tumor Models, In Vitro Functional Studies, and Cynomolgus Macaque Toxicology. PloS One 11, e0161779. doi: 10.1371/ journal.pone.0161779

Shao, Y., Liu, B., Di, Z., Zhang, G., Sun, L.-D., Li, L., et al. (2020). Engineering of Upconverted Metal-Organic Frameworks for Near-Infrared Light-Triggered Combinational Photodynamic/Chemo-/Immunotherapy against Hypoxic Tumors. J. Am. Chem. Soc. 142 (8), 3939-3946. doi: 10.1021/jacs.9b12788

Sheng, X., Yan, X., Chi, Z., Si, L., Cui, C., Tang, B., et al. (2019). Axitinib in Combination With Toripalimab, a Humanized Immunoglobulin G 4 Monoclonal Antibody Against Programmed Cell Death-1, in Patients With Metastatic Mucosal Melanoma: An Open-Label Phase IB Trial. J. Clin. Oncol. 37, 2987-2999. doi: 10.1200/JCO.19.00210

Shi, Z., Peng, X. X., Kim, I. W., Shukla, S., Si, Q. S., Robey, R. W., et al. (2007). Erlotinib (Tarceva, OSI-774) antagonizes ATP-binding cassette subfamily B member 1 and ATP-binding cassette subfamily G member 2-mediated drug resistance. Cancer Res. 67, 11012-11020. doi: 10.1158/0008-5472.can-07-2686

Shi, Z., Tiwari, A. K., Shukla, S., Robey, R. W., Singh, S., Kim, I. W., et al. (2011). Sildenafil reverses ABCB1- and ABCG2-mediated chemotherapeutic drug resistance. Cancer Res. 71, 3029-3041. doi: 10.1158/0008-5472.can-10-3820

Siegel, R. L., Miller, K. D., and Jemal, A. (2017). Cancer Statistics 2017. CA Cancer J. Clin. 67, 7-30. doi: 10.3322/caac.21387

Siegel, R. L., Miller, K. D., and Jemal, A. (2018). Cancer statistics, CA Cancer J. Clin. 68, 7-30. doi: 10.3322/caac.21442

Sonpavde, G., Necchi, A., Gupta, S., Steinberg, G. D., Gschwend, J. E., Van Der Heijden, M. S., et al. (2020). ENERGIZE: a Phase III study of neoadjuvant chemotherapy alone or with nivolumab with/without linrodostat mesylate for muscle-invasive bladder cancer. Future Oncol. 16, 4359-4368. doi: 10.2217/ fon-2019-0611

Sugiura, D., Maruhashi, T., Okazaki, I.-M., Shimizu, K., Maeda, T. K., Takemoto, T., et al. (2019). Restriction of PD-1 function by cis-PD-L1/CD80 interactions is required for optimal $\mathrm{T}$ cell responses. Science 364, 558. doi: $10.1126 /$ science.aav7062

Sui, J., Deming, M., Rockx, B., Liddington, R. C., Zhu, Q. K., Baric, R. S., et al. (2014). Effects of human anti-spike protein receptor binding domain antibodies on severe acute respiratory syndrome coronavirus neutralization escape and fitness. J. Virol. 88, 13769-13780. doi: 10.1128/JVI.02232-14

Swart, M., Verbrugge, I., and Beltman, J. B. (2016). Combination Approaches with Immune-Checkpoint Blockade in Cancer Therapy. Front. Oncol. 6, 233. doi: $10.3389 /$ fonc. 2016.00233

Syed, Y. Y. (2017). Durvalumab: First Global Approval. Drugs 77, 1369-1376. doi: $10.1007 / \mathrm{s} 40265-017-0782-5$

Sznol, M., and Chen, L. (2013). Antagonist antibodies to PD-1 and B7-H1 (PD-L1) in the treatment of advanced human cancer. Clin. Cancer Res. 19, 1021-1034. doi: 10.1158/1078-0432.ccr-12-2063 
Sznol, M. (2014). Blockade of the B7-H1/PD-1 pathway as a basis for combination anticancer therapy. Cancer J. 20, 290-295. doi: 10.1097/PPO.0000000000000056

Tian, H., Shi, G., Wang, Q., Li, Y., Yang, Q., Li, C., et al. (2019). Erratum: Author Correction: A novel cancer vaccine with the ability to simultaneously produce antiPD-1 antibody and GM-CSF in cancer cells and enhance Th1-biased antitumor immunity. Signal Transduct. Target. Ther. 4, 31. doi: 10.1038/s41392-019-0065-6

Tian, T., Lofftus, S., Pan, Y., Stingley, C. A., King, S. L., Zhao, J., et al. (2020). IL1 $\alpha$ antagonizes IL1 $\beta$ and promotes adaptive immune rejection of malignant tumors. Cancer Immunol. Res. 8 (5), 660-671. doi: 10.1158/2326-6066.CIR-19-0552

Tolcher, A. W., Sznol, M., Hu-Lieskovan, S., Papadopoulos, K. P., Patnaik, A., Rasco, D. W., et al. (2017). Phase Ib Study of Utomilumab (PF-05082566), a 41BB/CD137 Agonist, in Combination with Pembrolizumab (MK-3475) in Patients with Advanced Solid Tumors. Clin. Cancer Res. 23, 5349-5357. doi: 10.1158/1078-0432.CCR-17-1243

Trautmann, L., Janbazian, L., Chomont, N., Said, E. A., Gimmig, S., Bessette, B., et al. (2006). Upregulation of PD-1 expression on HIV-specific CD8+ T cells leads to reversible immune dysfunction. Nat. Med. 12, 1198-1202. doi: 10.1038/nm1482

Trino, E., Mantovani, C., Badellino, S., Ricardi, U., and Filippi, A. R. (2017). Radiosurgery/stereotactic radiotherapy in combination with immunotherapy and targeted agents for melanoma brain metastases. Expert Rev. Anticancer Ther. 17, 347-356. doi: 10.1080/14737140.2017.1296764

Turajlic, S., Gore, M., and Larkin, J. (2018). First report of overall survival for ipilimumab plus nivolumab from the phase III Checkmate 067 study in advanced melanoma. Ann. Oncol. 29, 542-543. doi: 10.1093/annonc/mdy020

Von Knethen, A., and Brüne, B. (2019). PD-L1 in the palm of your hand: palmitoylation as a target for immuno-oncology. Signal Transduct. Target. Ther. 4, 18. doi: 10.1038/s41392-019-0053-x

Wallin, J. J., Bendell, J. C., Funke, R., Sznol, M., Korski, K., Jones, S., et al. (2016). Atezolizumab in combination with bevacizumab enhances antigen-specific Tcell migration in metastatic renal cell carcinoma. Nat. Commun. 7, 1262412624. doi: $10.1038 /$ ncomms 12624

Wan, N., Zhang, T., Hua, S., Lu, Z., Ji, B., Li, L., et al. (2020). Cost-effectiveness analysis of pembrolizumab plus chemotherapy with PD-L1 test for the first-line treatment of NSCLC. Cancer Med. 9 (5), 1683-1693. doi: 10.1002/cam4.2793

Wang, M., and Wei, X. (2019). Deletion of the RNA-editing enzyme ADAR1A: new strategy to potentiate responses to PD-1 immune checkpoint blockade. Signal Transduct. Target. Ther. 4, 6. doi: 10.1038/s41392-019-0039-8

Wang, L., Yu, C., Yang, Y., Gao, K., and Wang, J. (2017). Development of a robust reporter gene assay to measure the bioactivity of anti-PD-1/anti-PD-L1 therapeutic antibodies. J. Pharm. Biomed. Anal. 145, 447-453. doi: 10.1016/ j.jpba.2017.05.011

Ward, M. C., Shah, C., Adelstein, D. J., Geiger, J. L., Miller, J. A., Koyfman, S. A., et al. (2017). Cost-effectiveness of nivolumab for recurrent or metastatic head and neck cancers. Oral. Oncol. 74, 49-55. doi: 10.1016/j.oraloncology.2017.09.017

Weinstock, C., Khozin, S., Suzman, D., Zhang, L., Tang, S., Wahby, S., et al. (2017). U.S. Food and Drug Administration Approval Summary: Atezolizumab for Metastatic Non-Small Cell Lung Cancer. Clin. Cancer Res. 23, 4534-4539. doi: 10.1158/1078-0432.ccr-17-0540

Weiss, J. M., Pennell, N., Deal, A. M., Morgensztern, D., Bradford, D. S., Crane, J., et al. (2020). Nab-paclitaxel in older patients with non-small cell lung cancer who have developed disease progression after platinum-based doublet chemotherapy. Cancer. 126 (5), 1060-1067. doi: 10.1002/cncr.32573

West, H., Mccleod, M., Hussein, M., Morabito, A., Rittmeyer, A., Conter, H. J., et al. (2019). Atezolizumab in combination with carboplatin plus nabpaclitaxel chemotherapy compared with chemotherapy alone as first-line treatment for metastatic non-squamous non-small-cell lung cancer (IMpower130): a multicentre, randomised, open-label, phase 3 trial. Lancet Oncol. 20, 924-937. doi: 10.1016/S1470-2045(19)30167-6

Wolchok, J. D., Kluger, H., Callahan, M. K., Postow, M. A., Rizvi, N. A., Lesokhin, A. M., et al. (2013). Nivolumab plus ipilimumab in advanced melanoma. N. Engl. J. Med. 369, 122-133. doi: 10.1056/NEJMoa1302369
Wolchok, J. D., Chiarion-Sileni, V., Gonzalez, R., Rutkowski, P., Grob, J.-J., Cowey, C. L., et al. (2017). Overall Survival with Combined Nivolumab and Ipilimumab in Advanced Melanoma. N. Engl. J. Med. 377, 1345-1356. doi: 10.1056/NEJMoa1709684

Wrangle, J. M., Velcheti, V., Patel, M. R., Garrett-Mayer, E., Hill, E. G., Ravenel, J. G., et al. (2018). ALT-803, an IL-15 superagonist, in combination with nivolumab in patients with metastatic non-small cell lung cancer: a non-randomised, openlabel, phase 1b trial. Lancet Oncol. 19, 694-704. doi: 10.1016/S1470-2045(18) 30148-7

Xu, C., Zhang, Y., Rolfe, P. A., Hernandez, V. M., Guzman, W., Kradjian, G., et al. (2017). Combination Therapy with NHS-muIL12 and Avelumab (anti-PD-L1) Enhances Antitumor Efficacy in Preclinical Cancer Models. Clin. Cancer Res. 23, 5869-5880. doi: 10.1158/1078-0432.CCR-17-0483

Younes, A., Brody, J., Carpio, C., Lopez-Guillermo, A., Ben-Yehuda, D., Ferhanoglu, B., et al. (2019). Safety and activity of ibrutinib in combination with nivolumab in patients with relapsed non-Hodgkin lymphoma or chronic lymphocytic leukaemia: a phase 1/2a study. Lancet Haematol. 6, e67-e78. doi: 10.1016/S2352-3026(18)30217-5

Yu, Y., and Lee, N. Y. (2019). JAVELIN Head and Neck 100: a Phase III trial of avelumab and chemoradiation for locally advanced head and neck cancer. Future Oncol. 15, 687-694. doi: 10.2217/fon-2018-0405

Yu, X., Huang, X., Chen, X., Liu, J., Wu, C., Pu, Q., et al. (2019). Characterization of a novel anti-human lymphocyte activation gene 3 (LAG-3) antibody for cancer immunotherapy. MAbs, 11 (6), 1139-1148. doi: 10.1080/ 19420862.2019.1629239

Zhang, J. Y., Lin, M. T., Tung, H. Y., Tang, S. L., Yi, T., Zhang, Y. Z., et al. (2016). Bruceine D induces apoptosis in human chronic myeloid leukemia K562 cells via mitochondrial pathway. Am. J. Cancer Res. 6, 819-826.

Zhang, J., Lai, Z., Huang, W., Ling, H., Lin, M., Tang, S., et al. (2017). Apicidin Inhibited Proliferation and Invasion and Induced Apoptosis via Mitochondrial Pathway in Non-small Cell Lung Cancer GLC-82 Cells. Anticancer Agents Med. Chem. 17, 1374-1382. doi: 10.2174/18715206176 66170419120044

Zhang, B., Wang, X., Li, Q., Mo, H., Wang, X., Song, Y., et al. (2019). Efficacy of irinotecan-based chemotherapy after exposure to an anti-PD-1 antibody in patients with advanced esophageal squamous cell carcinoma. Chi. J. Cancer Res. 31, 910-917. doi: 10.21147/j.issn.1000-9604.2019.06.07

Zhang, F., Huang, D., Li, T., Zhang, S., Wang, J., Zhang, Y., et al. (2020). Anti-PD1 Therapy plus Chemotherapy and/or Bevacizumab as Second Line or later Treatment for Patients with Advanced Non-Small Cell Lung Cancer. J. Cancer 11, 741-749. doi: 10.7150/jca.37966

Zhao, Y., Lee, C. K., Lin, C.-H., Gassen, R. B., Xu, X., Huang, Z., et al. (2019). PDL1:CD80 Cis-Heterodimer Triggers the Co-stimulatory Receptor CD28 While Repressing the Inhibitory PD-1 and CTLA-4 Pathways. Immunity 51, 1059 1073.e1059. doi: 10.1016/j.immuni.2019.11.003

Zimmer, A. S., Nichols, E., Cimino-Mathews, A., Peer, C., Cao, L., Lee, M.-J., et al. (2019). A phase I study of the PD-L1 inhibitor, durvalumab, in combination with a PARP inhibitor, olaparib, and a VEGFR1-3 inhibitor, cediranib, in recurrent women's cancers with biomarker analyses. J. Immunother. Cancer 7, 197. doi: 10.1186/s40425-019-0680-3

Conflict of Interest: The authors declare that the research was conducted in the absence of any commercial or financial relationships that could be construed as a potential conflict of interest.

Copyright (c) 2020 Zhang, Yan, Li, Adhikari and Fu. This is an open-access article distributed under the terms of the Creative Commons Attribution License (CC BY). The use, distribution or reproduction in other forums is permitted, provided the original author(s) and the copyright owner(s) are credited and that the original publication in this journal is cited, in accordance with accepted academic practice. No use, distribution or reproduction is permitted which does not comply with these terms. 